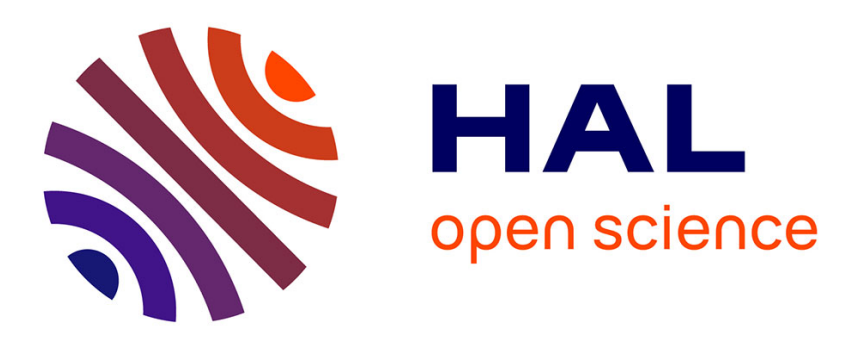

\title{
Cenozoic Stages of Forearc Evolution Following the Accretion of a Sliver From the Late Cretaceous-Caribbean Large Igneous Province: SW Ecuador-NW Peru
}

\author{
Carlos Aizprua, César Witt, Ståle Johansen, Diego Barba
}

\section{To cite this version:}

Carlos Aizprua, César Witt, Ståle Johansen, Diego Barba. Cenozoic Stages of Forearc Evolution Following the Accretion of a Sliver From the Late Cretaceous-Caribbean Large Igneous Province: SW Ecuador-NW Peru. Tectonics, 2019, 38 (4), pp.1441-1465. 10.1029/2018TC005235 . hal-02356126

\author{
HAL Id: hal-02356126 \\ https://hal.science/hal-02356126
}

Submitted on 22 Jun 2021

HAL is a multi-disciplinary open access archive for the deposit and dissemination of scientific research documents, whether they are published or not. The documents may come from teaching and research institutions in France or abroad, or from public or private research centers.
L'archive ouverte pluridisciplinaire HAL, est destinée au dépôt et à la diffusion de documents scientifiques de niveau recherche, publiés ou non, émanant des établissements d'enseignement et de recherche français ou étrangers, des laboratoires publics ou privés. 


\section{Tectonics}

\author{
RESEARCH ARTICLE \\ 10.1029/2018TC005235 \\ Key Points: \\ - This work is the first full \\ onshore-offshore revision of the \\ Paleocene-Quaternary evolution at \\ the trailing edge of the North \\ Andean Sliver \\ - The collision and docking of a \\ buoyant Late Cretaceous oceanic \\ crustal sliver may have influenced \\ the Cenozoic strain partitioning in \\ the region \\ - The accreted remnants and \\ preservation of an ancient \\ accretionary wedge may have \\ controlled the post-accretionary \\ forearc basin configuration
}

Correspondence to:

C. Aizprua,

calun@equinor.com

Citation:

Aizprua, C., Witt, C., Johansen, S. E., \& Barba, D. (2019). Cenozoic stages of forearc evolution following the accretion of a sliver from the Late Cretaceous-Caribbean large igneous province: SW Ecuador-NW Peru. Tectonics, 38, 1441-1465. https://doi. org/10.1029/2018TC005235

Received 10 JUL 2018 Accepted 1 MAR 2019

Accepted article online 12 MAR 2019

Published online 18 APR 2019

(C)2019. American Geophysical Union. All Rights Reserved.

\section{Cenozoic Stages of Forearc Evolution Following the Accretion of a Sliver From the Late Cretaceous-Caribbean Large Igneous Province: SW Ecuador-NW Peru}

\author{
Carlos Aizprua $^{1,2,3}$ (D), Cesar Witt ${ }^{2}$, Ståle E. Johansen ${ }^{1}$, and Diego Barba ${ }^{4}$ \\ ${ }^{1}$ Department of Geoscience and Petroleum, Norwegian University of Science and Technology (NTNU), Trondheim, \\ Norway, ${ }^{2}$ Laboratoire d'Océanologie et de Géosciences, Université de Lille, CNRS, Université du Littoral Côte d'Opale, \\ UMR 8187, LOG, Lille, France, ${ }^{3}$ Now at Equinor ASA, Bergen, Norway, ${ }^{4}$ Petroamazonas EP, Quito, Ecuador
}

\begin{abstract}
The SW Ecuador-NW Peru forearc region is the southernmost location, where the Caribbean large igneous province (CLIP) interacted with the South American margin since the Late Cretaceous. The accretion of the CLIP to the margin led to the entrapment of the North Andean crustal Sliver, conforming the underlying basement of the forearc region in Ecuador, whereas in NW Peru, forearc depocenters involve rocks of continental affinity. Many existing tectonic reconstructions have treated these two areas independently, largely based on their crustal affinities. In contrast, this study integrates previous studies into an analysis of unpublished seismic profiles, potential field data, outcrop stratigraphy, and recent studies dealing with the dynamics of allochthonous terrane accretion along continental margins. Our integrated approach shows that SW Ecuador was dominated by a Late Cretaceous deforming outer wedge, which may have constituted a remnant of a northeast or northwest dipping obliquely obducted oceanic block at the edge of the CLIP. This tectonic phase was governed by plate instability, affecting NW Peru and SW Ecuador, followed by reestablishment of the margin by early Eocene. The resulting margin configuration and the spatial distribution of the different tectonic elements seem to have played a key role into the further Cenozoic development of the forearc region. The model presented in this study proposes that the accretion of buoyant oceanic terranes may have had a profound impact on the early margin configuration of SW Ecuador and NW Peru and led to the development of localized but genetically related forearc depocenters.
\end{abstract}

\section{Introduction}

Forearc basins along convergent margins are characterized by complex structural configurations and sedimentary infilling that are primarily governed by the erosional versus accretionary tectonic regime along the margin (Beck, 1983; Haq \& Davis, 2010; Kopp, 2013; McCaffrey, 1992; Noda, 2016; Pinet \& Cobbold, 1992; Platt, 1993; Seely, 1979; Von Huene \& Scholl, 1991). The sedimentary record can provide valuable information about past episodes, but the information may be biased by the better preserved geological evidence (Draut \& Clift, 2013). Ancient forearc regions are commonly composed of amalgamations of continental fragments, intra-oceanic island arcs, or the entrapment of oceanic plateau slivers (e.g., Costa Rica margin, Andjić et al., 2018; Great basin, Dickinson, 2013; NW South America, Kerr \& Tarney, 2005), making it imperative to account for their role in the tectonostratigraphic evolution of forearc basins.

Recent numerical models of the dynamics of oceanic plateau accretion versus subduction along continental margins show a strong link with the topographic evolution of the forearc region (Moresi et al., 2014; Vogt \& Gerya, 2014). Moresi et al. (2014) suggest that the dynamics of the accretion of buoyant and/or exotic plates or microplates are marked by three stages: (1) a collision stage leading to the accretion of the crust; (2) a transitional stage marked by coeval advance and trench retreat in different parts of the margin; and (3) the reinitiation of a stable subduction system behind the accreted microplate.

The seaward flanks of the Northern Andes are underlain by allochthonous oceanic terranes derived from the Caribbean large igneous province (CLIP) (Whattam \& Stern, 2015) that were episodically accreted to the South American continent from the Late Campanian to the Paleocene (Hughes \& Pilatasig, 2002; Jaillard et al., 1997; Luzieux et al., 2006; Mamberti et al., 2003; Reynaud et al., 1999; Vallejo et al., 2009), which 


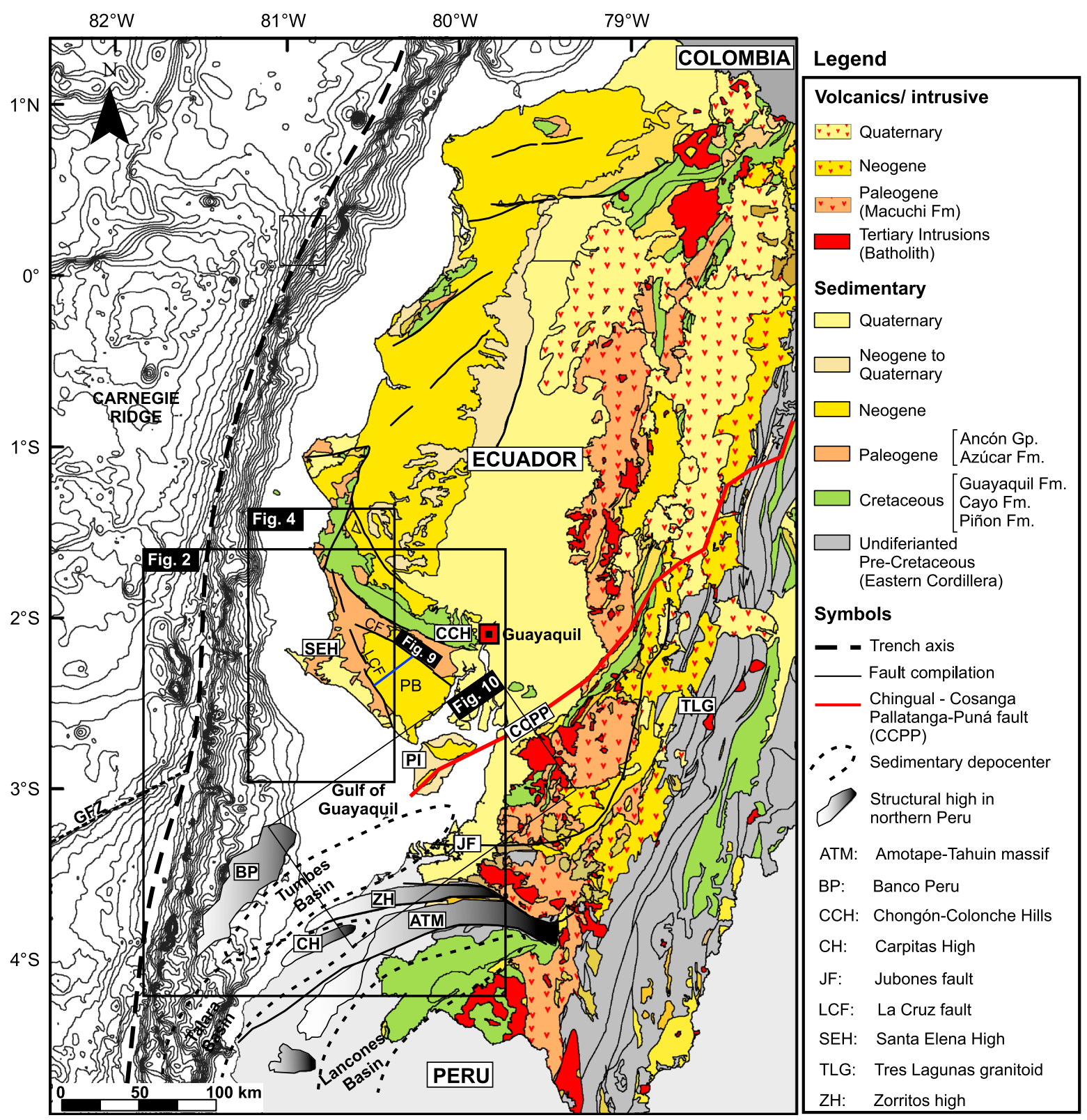

Figure 1. Regional geology of southwestern Ecuador displaying the present-day spatial relationship of the different geological units. Black lines show the major structural lineaments of the study area. Geological units and major faults are compiled from previous studies (Bosch et al., 2002; Espurt et al., 2017; Fildani et al., 2008; Herms et al., 2012; Hungerbühler et al., 2002; Kerr et al., 2002; Mamberti et al., 2003; Reynaud et al., 1999; Spikings et al., 2005; Vallejo et al., 2009; Winter et al., 2010; Witt \& Bourgois, 2010).

led to the entrapment of the North Andean sliver (Alvarado et al., 2016; Kennan \& Pindell, 2009). At the trailing edge of the North Andean sliver, the peculiarly oriented Gulf of Guayaquil-Tumbes and Progreso basins are located along a major shear zone coincident with a complex suture zone between oceanic and continental crustal terranes, which probably marks the southern edge of the CLIP (Figure 1) (Aizprua et al., 2017; Deniaud et al., 1999; Jaillard et al., 2009; Witt et al., 2006).

The collision and accretion of the CLIP to the margin is well documented along the western Cordillera (Mamberti et al., 2003; Reynaud et al., 1999; Vallejo et al., 2009). However, the initial interaction between the trailing edge of the CLIP and the margin and its role into the further Cenozoic forearc basin development in SW Ecuador and NW Peru has not been discussed in detail (Benitez, 1995; Espurt et al., 2017; Fildani et al., 2008; Jaillard et al., 1995; Witt \& Bourgois, 2010). 

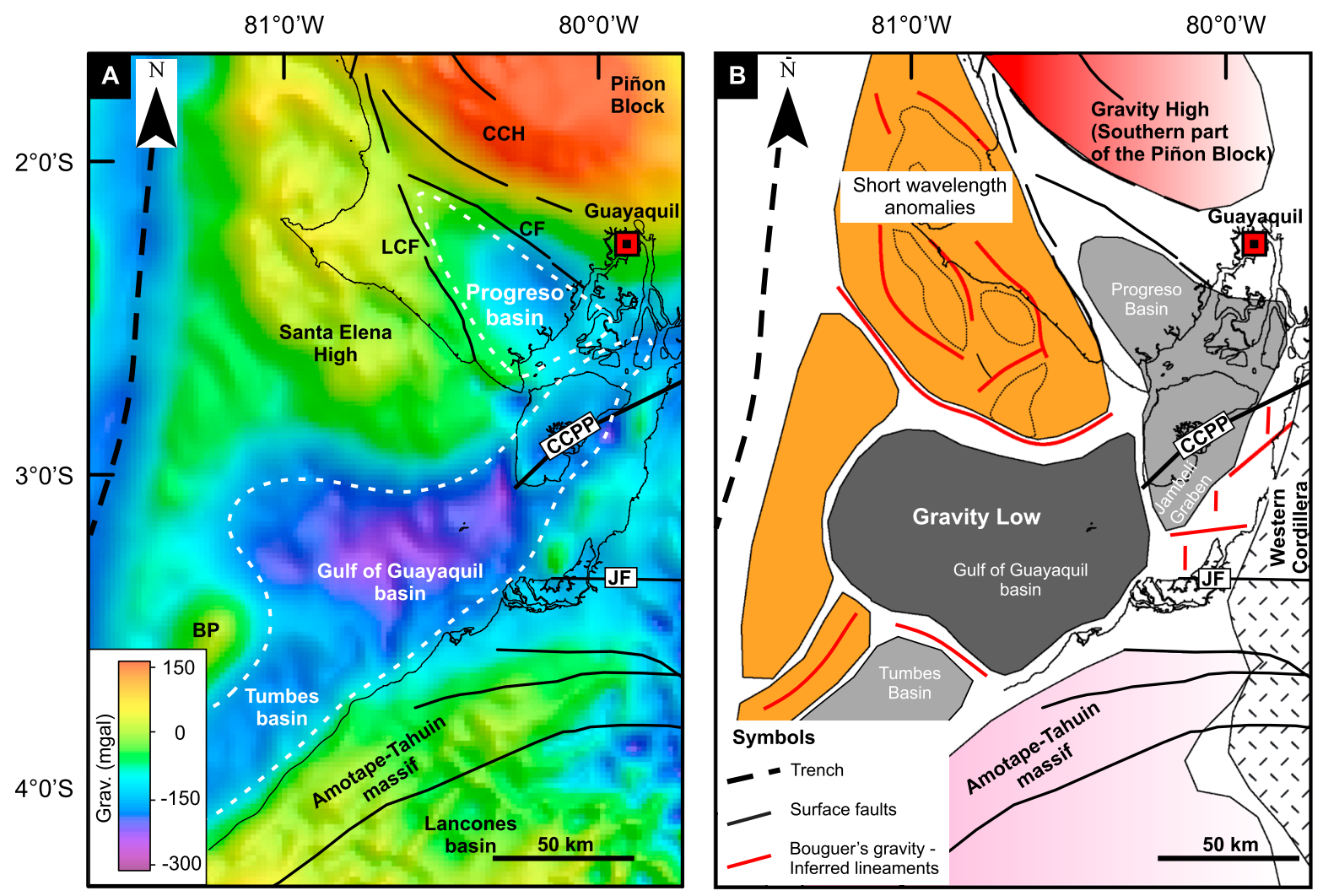

Figure 2. (a) Bouguer's gravity anomaly map in SW Ecuador (Sandwell et al., 2014). (b) Main structural lineaments derived from gravity gradients are highlighted in red. Notice the three main domains derived from the Bouguer's gravity anomaly: (1) in red an area of long wavelength anomaly that corresponds to surfaces exposures from the Piñon block, (2) in orange an area dominated by short wavelength anomalies directly linked to the Santa Elena High, and (3) negative values corresponding to the thick sedimentary successions along the Gulf of Guayaquil-Tumbes basin. BP: Banco Peru; CCH-Chongón Colonche Hills; CCPP: ChingualCosanga-Pallatanta-Puná; CF-Carrizal fault; JF: Jubones fault; LCF: La Cruz fault.

Using an integrative data approach, we present a model depicting the tectonostratigraphic response to the accretion of an oceanic plateau along the transform boundary between its southern edge and the NW South American continental margin. The distribution of the different tectonic elements across the study area suggests a natural example of the numerical simulations proposed by Moresi et al. (2014) and Vogt and Gerya (2014), at least until the middle to late Eocene. Since at least the Oligocene, the resulting margin configuration appears to have controlled the development of the Gulf of Guayaquil-Tumbes basins through transtensional movements, and the Progreso basin as a sensu stricto forearc basin that was controlled by the development of an outer forearc high buttress with a remnant of the CLIP (Piñon Block) acting as a backstop (Figure 2). These aspects bring new insights into the evolution of the Ecuador-Peru forearc region, which have general implications for the tectonostratigraphic architecture of forearc regions affected by the accretion of allochthonous terranes.

\section{Geodynamic and Geological Settings}

\subsection{North Andean Sliver}

Coastal Ecuador is composed of terranes with plateau and island-arc affinities (e.g., Hughes \& Pilatasig, 2002; Kerr et al., 2002, 1997; Reynaud et al., 1999). Paleomagnetic studies along the Chongón Colonche Hills (Figure 1) reveal a low-latitude $\left(\sim 0-10^{\circ} \mathrm{S}\right)$ origin for the Cretaceous mafic rocks exposed in coastal Ecuador and clockwise rotations ranging from 20 to $70^{\circ}$ during the Late Campanian, which were likely triggered by the collision with the South American plate (Luzieux et al., 2006; Roperch et al., 1987). Potential field models across the North Andean sliver support the presence of an underlying oceanic crust (Feininger \& Seguin, 1983; Kellogg et al., 1995). Feininger and Seguin (1983) propose a sharp and vertical 
boundary between the oceanic terrane and the South American continental crust and suggest a shallow mantle interpretation to explain the high positive Bouguer gravity anomaly coincident with the strike of the Chongón Colonche Hills (Figure 2). Kellogg et al. (1995) instead propose a low-angle obduction of the oceanic crust supported by velocity inversion results along a refraction profile farther north, along the border between Ecuador and Colombia.

The accreted mafic rocks form the basement of coastal Ecuador, and they are mainly confined between the major dextral Chingual-Cosanga-Pallatanga-Puná fault system to the east (Alvarado et al., 2016), the trench to the west, and a complex suture zone to the south that runs along the Gulf of Guayaquil (Aizprua et al., 2017) (Figure 1). Despite several studies on the nature and origin of the basement of coastal Ecuador, its emplacement along the margin is still a topic of debate. This has led to two main and opposing models for its emplacement: one incorporates a single accretionary episode during the Maastrichtian (e.g., Vallejo et al., 2009), and the other includes multiple accretionary episodes between the Late Cretaceous and the Eocene (Hughes \& Pilatasig, 2002; Jaillard et al., 2009; Kerr et al., 2002).

Deformation partitioning affected the Northern Andes from southwest Ecuador to northern Colombia and formed the regional North Andean sliver (Alvarado et al., 2016; Ego et al., 1996; Nocquet et al., 2014; Yepes et al., 2016). The northeastward movement of the North Andean sliver resulted in clear north-south striking transpressive deformation along the eastern boundary of the sliver (Winkler et al., 2005), which suggests that the deformation was induced by oblique subduction. A fault analysis performed in the western Cordillera led Alvarado et al. (2016) to propose that the northward migration of the sliver may have started during the middle Miocene ( $15 \mathrm{Ma}$ ). Furthermore, rapid subsidence resulting in thick Quaternary basin formation in the Gulf of Guayaquil was associated with an acceleration of the tectonic escape of the sliver for at least the last $1.8 \mathrm{Ma}$ in a process that may have resulted from a stronger coupling with the subducting Carnegie Ridge (Egbue \& Kellogg, 2010; Michaud et al., 2009; Witt et al., 2006).

\subsection{Basin Stratigraphy of SW Ecuador}

The Bouguer gravity anomaly map of the study area (Figure 2) highlights the locations and extents of the different forearc basins. Both the Santa Elena High and the Chongón-Colonche Hills are prominent features that played key roles in the segmentation of the forearc region.

The Piñon Block, which is part of the CLIP region, outcrops along the Chongón-Colonche Hills (Figures 1 and 2). Near the city of Guayaquil, the Piñon Block contains a nearly complete volcanoclastic sequence with stratigraphic contacts striking ESE-WNW (Figures 1 and 3). Figure 3 shows the stratigraphy of the area, from tholeiitic basalts and pillow lavas of the Piñon Formation to flysch and volcaniclastic deposits of the Cayo Formation, which are unconformably covered by chertized turbidite deposits of the Guayaquil Formation (Benitez, 1995). Farther to the SW, highly deformed equivalents of the Guayaquil Formation are exposed along the Santa Elena Peninsula (Figure 3).

2.2.1. Santa Elena Peninsula

A significant tectonostratigraphic change occurs south of the Chongón-Colonche Hills (Figures 4 and 5a), where highly deformed layers of the Late Cretaceous Santa Elena Formation, which are age equivalent to the Guayaquil Formation, are unconformably overlain by acidic rocks of the Late Paleocene Azúcar Formation (Figure 5b). This formation is only present south of the Chongón-Colonche Hills, which is evidence of input from a localized continental source during this period. Paleocene outcrops near the city of Playas (Figures 4 and 5c) show a sequence of conglomerates alternating with coarse sand layers within a channelized conforming geometry, which are likely part of a submarine canyon architecture with a major paleocurrent direction pointing northward (Benitez, 1995; Jaillard et al., 1995; Moreno, 1983). Similar surface exposures show vertically dipping layers, indicating that a relatively high degree of postsedimentary deformation occurred by the end of the Paleocene or early Eocene (Figure 5c).

Farther to the west, middle Eocene rocks unconformably overlie the Azúcar Formation (Figure 5a). Middle Eocene rocks of the Ancón Group are characterized by minor normal faulting and major gravitational sedimentary structures (at least in the basal part; Figure 5e) during a period that may have resulted from a relaxation process accommodated by extensional tectonics (Jaillard et al., 1995). These authors suggest that during the Eocene, sediments were deposited on top of an accretionary slope-basin and were subsequently affected by several deformation phases with different orientations that derived from an oblique subduction 


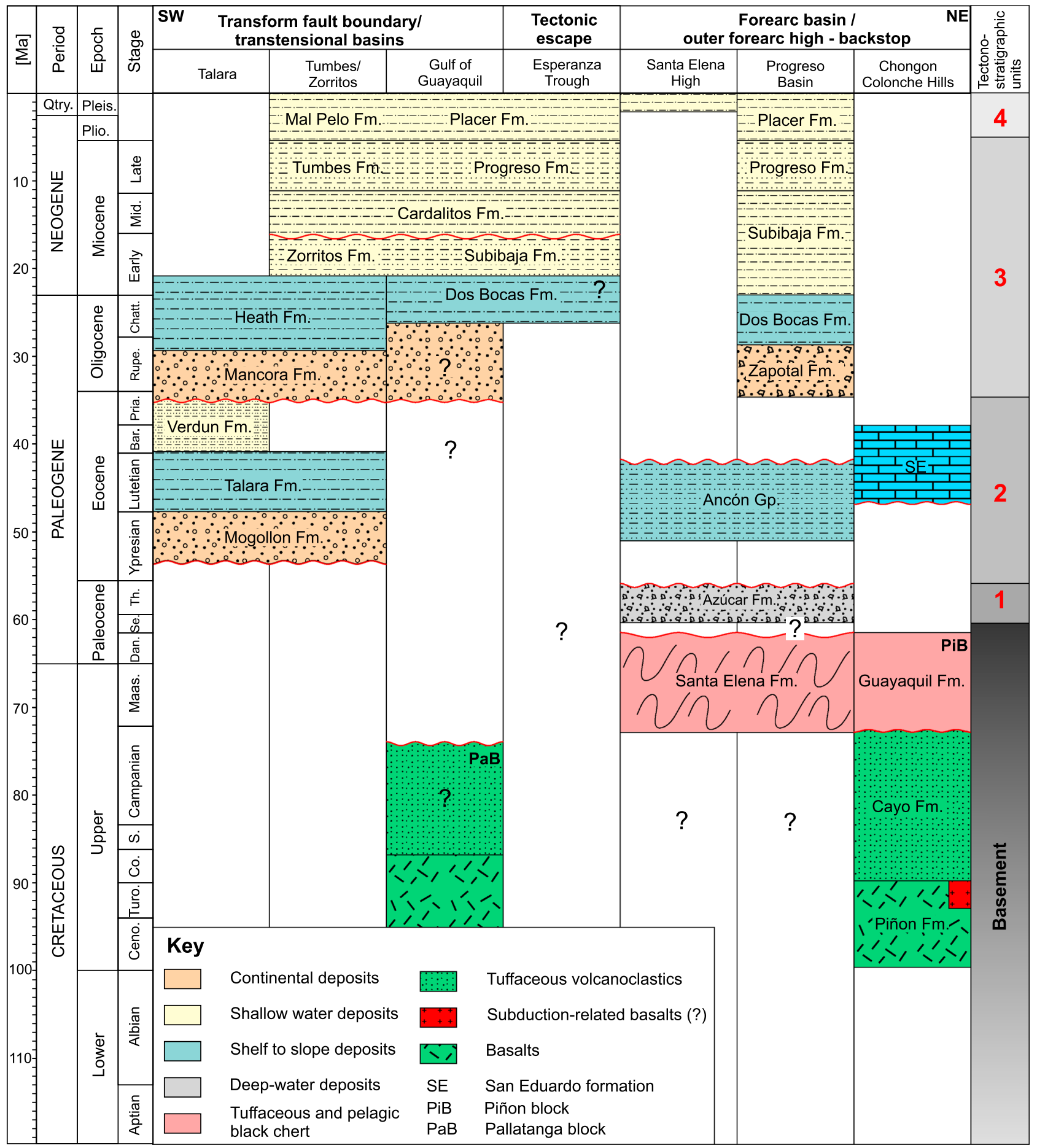

Figure 3. Chronostratigraphic chart of the SW Ecuador and NW Peru (modified after Benitez, 1995; Espurt et al., 2017; Fildani et al., 2008; Jaillard et al., 1995). The upper part of the chart displays the structural domains interpreted from this study and the location of the different stratigraphic columns. Toward the NE, within the forearc basin domain, the stratigraphy of the accreted oceanic terrane (Piñon block) is displayed. At the center, the Esperanza trough is within the tectonic escape domain, which is characterized by very negative Bouguer's anomaly values (Figure 2) and thick Pleistocene sequences (Witt et al., 2006). Toward the SW, the Eocene sequences found within the Talara and Tumbes basins lies unconformably over Paleozoic metasediments (not displayed). Numbers 1 to 4 indicate the tectonostratigraphic units discussed in this study: $1=$ high density deep marine deposits and highly deformed Paleocene sequences; $2=$ slope sedimentary sequences; 3 = shallow sedimentary sequences, and $4=$ thick Quaternary sequences following the tectonic escape of the North Andean sliver. 

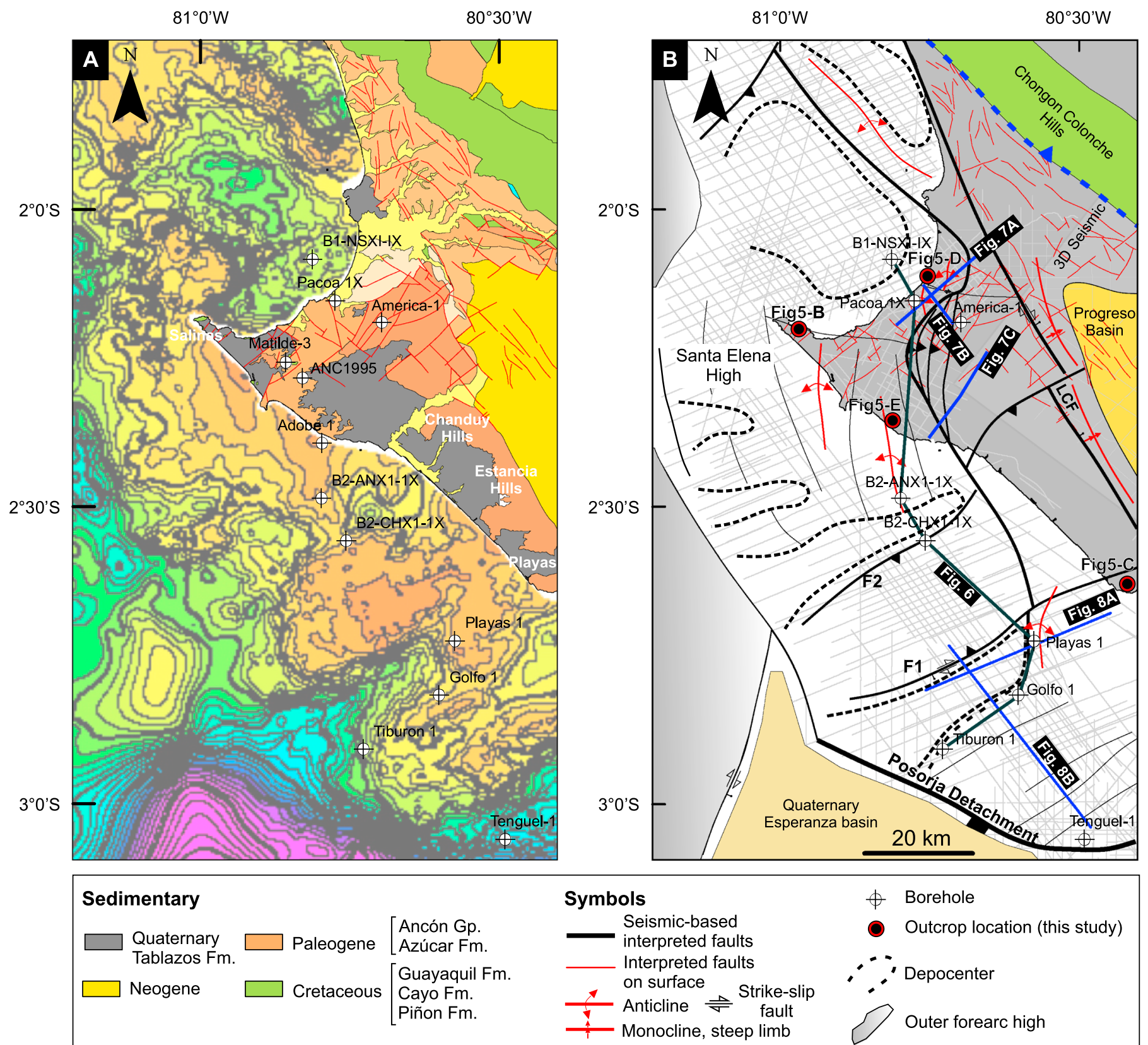

Figure 4. (a) Geological map and two-way traveltime (TWT) map of the major unconformity (U1/U2) across the Santa Elena High. (b) Structural map showing the main structural lineaments identified from interpreted seismic profiles. Faults identified on seismic sections in black, folded structures in thick red lines, and faults identified on surface on thin red lines.

system. The latest possibly within a tectonic framework influenced by the generation of a triple junction at the interaction of the Gorgona Plateau (Late Cretaceous), the east dipping Farallon plate (affecting western Ecuador), and the North Andean sliver (Kerr \& Tarney, 2005). By the end of the Eocene, the entire area emerged, and the sedimentary infilling of the basin evolved to a more continental setting (Benitez, 1995; Jaillard et al., 1995; Jaillard et al., 1997; Witt et al., 2019).

\subsubsection{Progreso and Gulf of Guayaquil-Tumbes Basins}

The Progreso basin is an Oligo-Pliocene basin located between the Chongón-Colonche Hills and the Santa Elena High (Figures 1 and 2). The basin has a NW-SE axis and a triangular shape that expands toward the SE (Figure 2). Its southwestern limit coincides with the La Cruz fault (Figure 1). Benitez (1995) summarizes the main stratigraphic units, which reflect a restricted basin with localized sediment input 

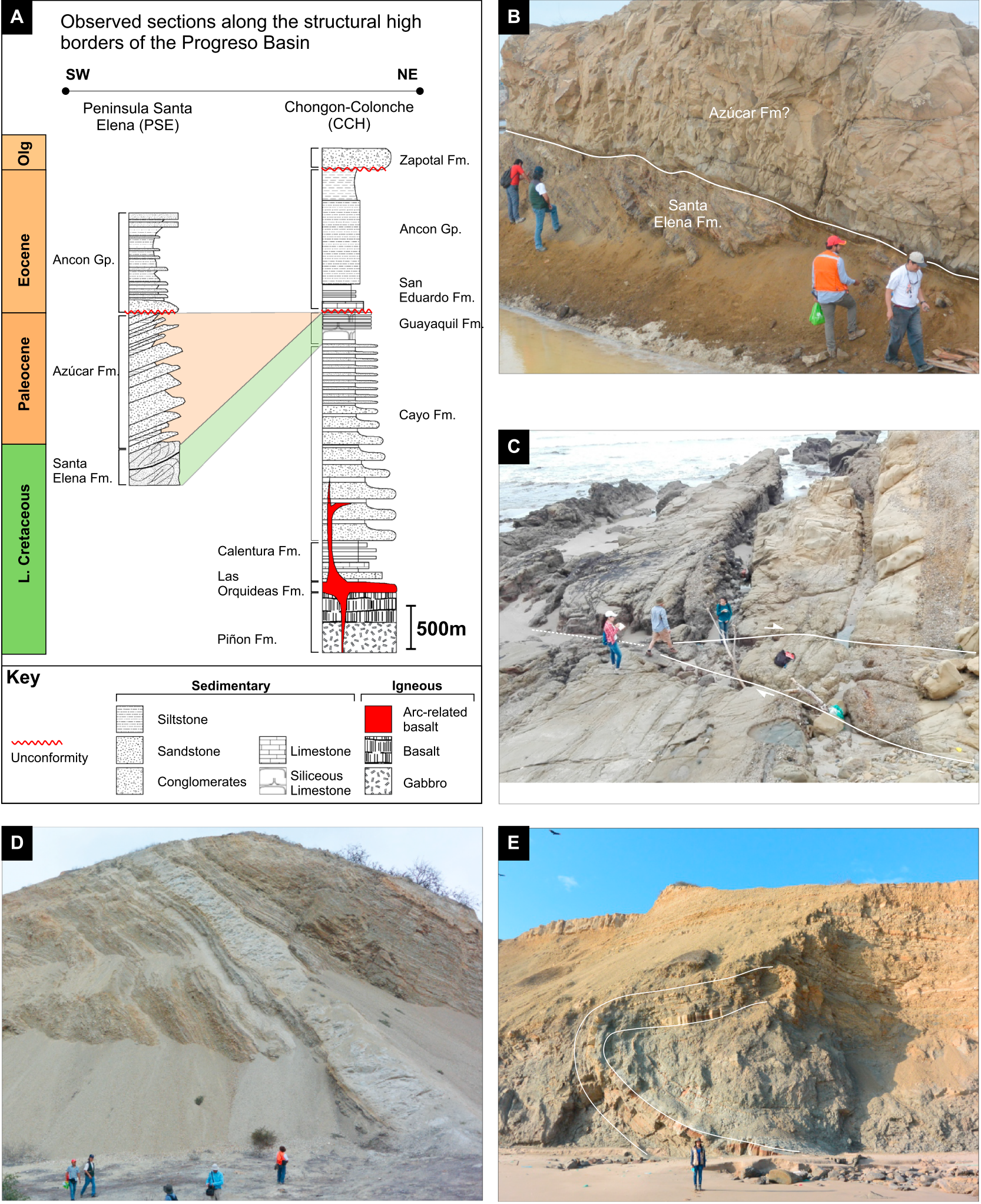

Figure 5. (a) Stratigraphy column of SW Ecuador for the Santa Elena Peninsula and Chongón Colonche Hills areas. (b) Chertified sediments of the Santa Elena Formation overlain discordantly by deposits of the Azúcar Formation near the city of Salinas (location in Figure 4). (c) Vertical strata of the Paleocene Azúcar Formation, outcrop located near the city of Playas showing high dense turbiditic deposits possibly in a confined channelized architecture. (d) Southern flank of a tight folded structure near the Pacoa oil field, deposits classically associated to the Ancón Group. (e) Middle Eocene sequences of the Ancón Group (within the Ancón oil field) showing a gravitational and mass transport complex structure. 
derived from the Chongón-Colonche Hills and the Santa Elena High. The underlying basement is believed to have been formed of the same complex and deformed sequences of Late Cretaceous to Paleocene age that are observed along the Santa Elena High. After emersion of the Santa Elena High during the late Eocene-early Oligocene, the Progreso basin began to form as a restricted area with a rapid shift to a continental to shallow marine environment (Witt et al., 2019). This is supported by the immature sediments of the Oligocene Zapotal Formation (Figure 3), which have paleocurrent directions that point toward the center of the basin (Benitez, 1995). The Miocene and Plio-Quaternary sedimentary rocks continued to develop in a restricted shallow marine environment with a marine influence possibly through the Gulf of Guayaquil.

South of the Santa Elena High, the Gulf of Guayaquil-Tumbes basin is described as an elongated basin, oriented in NE-SW direction, which is coincident with a marked gravity low (Figures 1 and 2). It includes the so-called Jambelí channel or graben, the offshore Tumbes basin, and the deep Esperanza sub-basin (part of the Gulf of Guayaquil basin; Figure 2, Benitez, 1995; Deniaud et al., 1999; Witt \& Bourgois, 2010). It is bounded to the north by the Posorja detachment, to the south by the Tumbes detachment, to the west by the Domito fault system, and to the east possibly by Late Cretaceous oceanic terranes (see details in Witt \& Bourgois, 2010).

The area has experienced a very high subsidence rate at least since the late Pliocene. Seismic profiles and borehole data clearly indicate a thick sedimentary succession of Quaternary sediments (Witt et al., 2006). Witt and Bourgois (2010) conclude that the thick Quaternary section of the Gulf of Guayaquil is the result of an acceleration of the NE migration of the North Andean Sliver (approximately $1 \mathrm{~cm} /$ year), which is possibly explained by the arrival of the Carnegie Ridge at the subduction zone.

\subsection{Northern Peru}

\subsubsection{The Amotape-Tahuin Massif}

The Amotape-Tahuin massif is a mountain range that trends E-W at the Ecuador-Peru border and changes to a NE-SW trend to the southwest (Figure 1). A series of positive Bouguer gravity anomalies have been identified along the NW coast of Peru, suggesting a very dense underlying basement along the Amotape-Tahuin massif that may indicate an allochthonous origin for the latest (Feininger, 1987). Mourier et al. (1988) list some of the main geological processes and stratigraphic sequences that have been identified along the AmotapeTahuin massif and how they differed from those observed farther east along the eastern Cordillera, which supports the analysis of Feininger and Seguin (1983). Furthermore, paleomagnetic studies from the AmotapeTahuin massif indicate clockwise rotations of approximately 35 to $90^{\circ}$ during the Late Cretaceous-Early Paleocene (Mourier et al., 1988), a rotation probably associated to the collision and accretion of the CLIP observed north of the massif in western Ecuador (Luzieux et al., 2006). However, geochemical and thermochronological data from rock samples along the Amotape-Tahuin massif complex show affinities with the Tres Lagunas Triassic granitoids (TLG) that are located farther northeast along the eastern Cordillera (Figure 1), which suggest that the Amotape-Tahuin massif is a translated sliver by clockwise rotation during the Early to Late Cretaceous (Aspden et al., 1992; Sanchez et al., 2006; Spikings et al., 2005). This is corroborated by recent similarities between age clusters and the maximum depositional ages of metasediments of the Amotape-Tahuin massif and the eastern Cordillera of Ecuador and Peru (Witt et al., 2017).

\subsubsection{Lancones-Talara Basins}

The Lancones and Talara basins in NW Peru comprise a series of NE-SW forearc depocenters bounded by thrust-related structural highs with a sequential northwestward progradation (Figure 1, Espurt et al., 2017). Paleomagnetic results from the Lancones basin show clockwise rotations on the order of $\sim 38^{\circ}$ (Mitouard et al., 1990), indicating that the basin was affected by dextral movements that were probably coincident with the increased exhumation rates in the Amotape-Tahuin massif at 75-65 Ma (Jaillard et al., 1999; Spikings et al., 2005).

The Talara basin, which is located northwest of the Amotape-Tahuin massif (Figure 1), is overlain by Eocene deposits comprising fluvial to deep marine strata that are mainly sourced from Paleozoic basement of the western Cordillera of Peru and the Amotape-Tahuin massif (Espurt et al., 2017; Fildani et al., 2008; Hessler \& Fildani, 2015; Witt et al., 2017). The Talara basin is bounded to the north by the subsurface Carpitas High, which separates it from the Tumbes basin (Figure 1). The sedimentary succession thickens to the south from $\sim 3.5 \mathrm{~km}$ to $9 \mathrm{~km}$, where exploration boreholes penetrated Paleocene strata (Fernández et al., 2005). Fildani et al. (2008) provide a detailed stratigraphic study of the Eocene deposits, which 

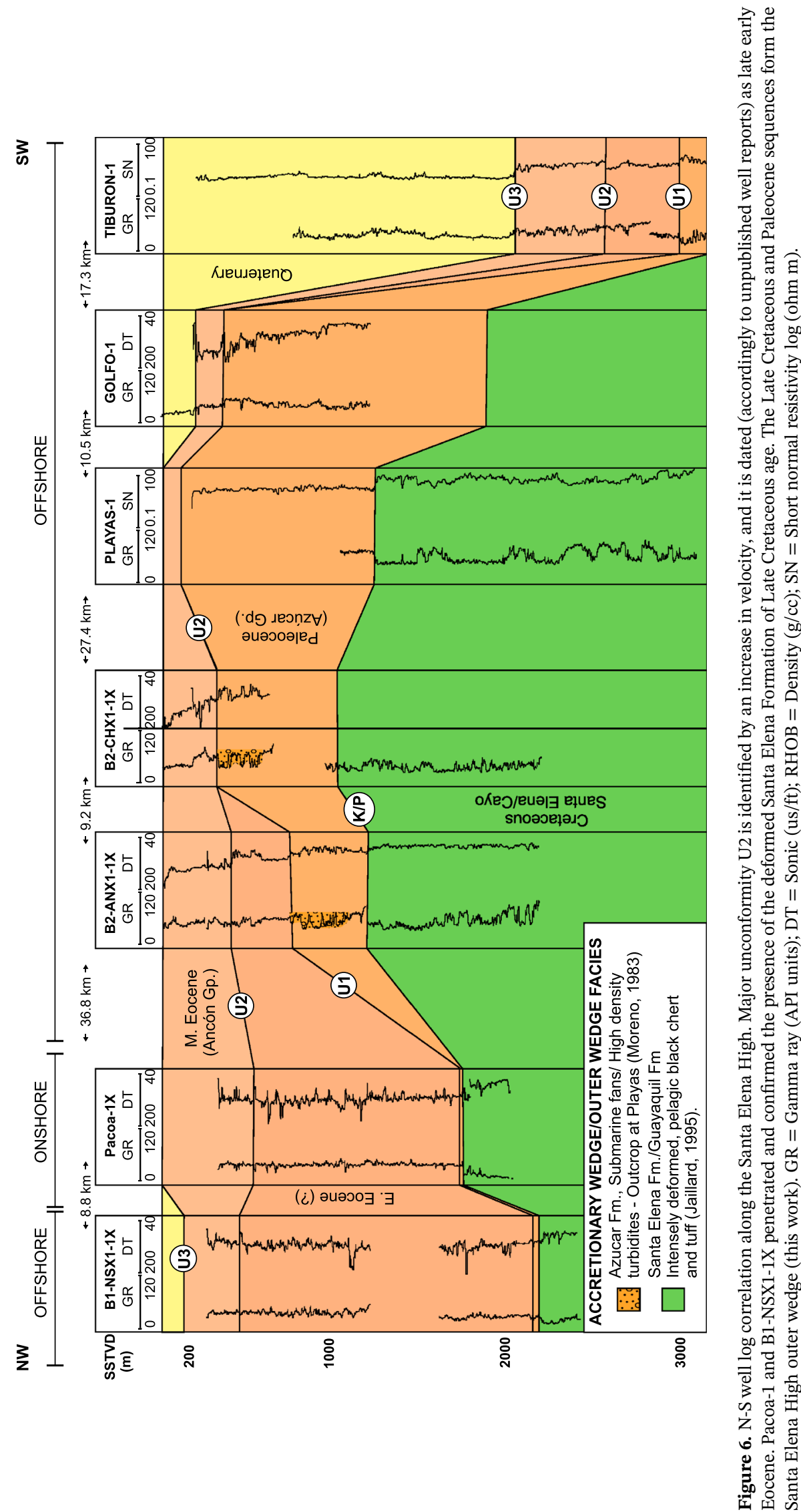
record a tectonically abrupt deepening of the basin in the middle Eocene that controlled the transition from deltaic and fluvial deposits to deep-water strata; these authors attributed this event to collisional tectonics and terrane accretion along the Ecuadorian margin. Mitouard et al. (1990) reported post-Paleocene clockwise rotations for northern Peru, an event that Spikings et al. (2005) suggest was coincident with the high exhumation rates of the Amotape-Tahuin massif during the middle Eocene to early Oligocene.

\section{Data Set and Methodology}

Hydrocarbon exploration has been performed in the study area for at least a century. The discoveries were mainly based on oil seeps along the southern coast of the Santa Elena Peninsula, which triggered further exploration campaigns. This study is based on the compilation of 2D industrial seismic profiles, borehole data, and internal unpublished reports provided by Petroamazonas EP, the Ecuadorian national oil and gas company (Aizprua et al., 2019). In NW Peru, we used two 2D seismic survey campaigns and four exploration boreholes to delimit the Tumbes basin. The industrial multichannel seismic reflection data in Ecuador and Peru are mainly composed of 2D seismic surveys and processing sequences with varying qualities from good to fair. Additionally, we used information from two unpublished 3D seismic surveys within the study area, one covering the offshore Amistad gas field and the second located onshore in the central Progreso basin. The borehole data are sparse in the area but in some cases provide relatively poor age control, especially in the deepest part of the Gulf of Guayaquil and on the Santa Elena High. In NW Peru, the age control for the different seismic units was obtained from a public report written by Perupetro, the national oil and gas company in Peru (Fernández et al., 2005).

A structural seismic interpretation across the offshore domain was performed to define the possible link between the offshore subsurface structures with structures that have been mapped onshore. A special focus was placed on mapping the southern extension of the Santa Elena High and its transition into the Gulf of Guayaquil (Figure 4). The stratigraphic interval encountered across the Santa Elena High plays a key role in the geology of southwestern Ecuador due to its interaction with the South American plate during the emplacement of the CLIP. The definition of the main structures and their orientations are discussed in detail in the next section.

The results from previous studies of the surface geology of the Santa Elena Peninsula have been incorporated to discuss the structural styles and deformational phases that may have affected the region. The geological markers obtained from these studies were included in the definition of the stratigraphic tops. During this study, the main outcrop localities along the southern coast of Ecuador were visited for structural and stratigraphic investigations. This study also benefited from radiometric ages, mostly zircon U-Pb ages (see Witt et al., 2019, 2017 for additional details).

\section{Results}

The results of the mapping include: (1) a Late Paleocene unconformity (U1), which, based on exploration boreholes, defines an unconformable contact between Early Eocene and Paleocene rocks; (2) an early Eocene unconformity (U2), which is a major boundary with the Late Paleocene U1 across the different structural highs (Figure 6); (3) a Middle to Late Eocene unconformity (U3) that is recognized mainly in the Santa Elena and Progreso regions; and (4) an early Miocene unconformity (U4) in the Gulf of Guayaquil, which was identified from industrial boreholes and long amplitude incisions on the eastern side of the Tumbes basin. The latter event corresponds to one of the main hydrocarbon reservoir intervals within the Gulf of Guayaquil-Tumbes basin. The acoustic basement identified on seismic profiles, underlying the main tectonostratigraphic units, is characterized by at least two different seismic facies that can be traced locally: (1) thick packages of high-amplitude and subparallel reflections, which, according to borehole Pacoa-1, correspond to the Late Cretaceous Santa Elena/Guayaquil Formation (Figure 7a), and (2) chaotic and dipping discontinuous reflections that possibly correspond to the crustal Piñon Block.

Based on our analysis, we subdivided the study area into different forearc regions characterized by their structural styles and sedimentary infilling, which are described further in the following sections.

\subsection{Santa Elena High}

It is a region characterized by positive and short wavelength gravity anomalies, located south of a gravity high, the latest one coincident with surface exposures of the Piñon Block (Figure 2). Its northeastern limit 

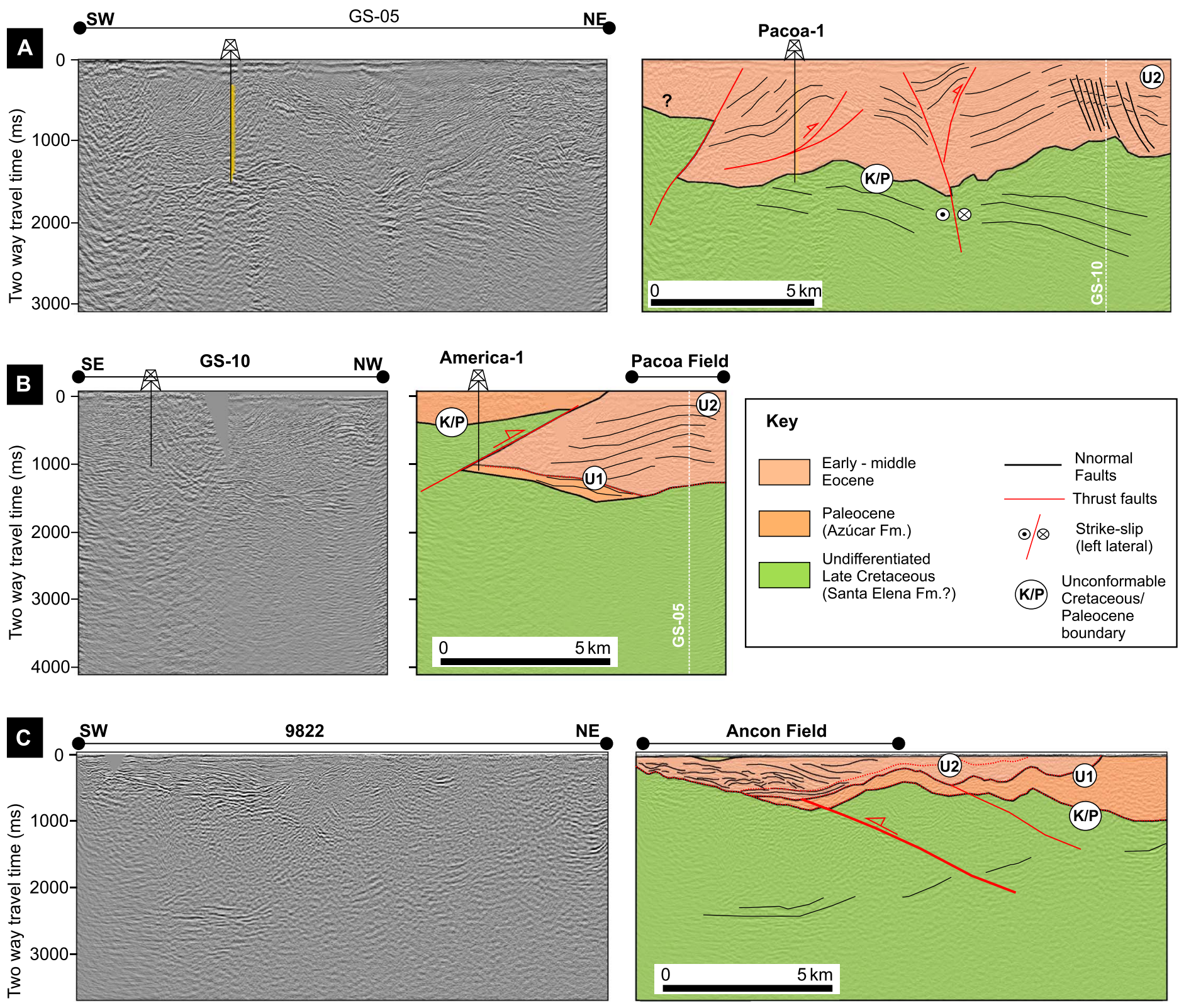

Figure 7. (a) Seismic profile across the Pacoa field showing the presence of folded and thrusted structures unconformably overlying the deformed Late Cretaceous series of the Santa Elena Formation. (b) Seismic profile perpendicular to Figure 7a showing an overthrust of the Late Cretaceous/Paleocene series onto possibly early to middle Eocene sedimentary successions. (c) Seismic profile showing a possible piggy-back basin with middle Eocene deposits from the Ancón Group noticed at the base the chaotic and inland seismic reflection packages overlain by more parallel to subparallel reflections.

is defined very well by the La Cruz Fault and the Progreso basin, a boundary that is laterally changing to the northwest, into an apparent direct contact between the Santa Elena High and the Chongón Colonche Hills (Figure 2). Based on the study of surface exposures (Figure 1) and the analysis of well and seismic data, we present the results dividing the Santa Elena High into the region exposed along the Santa Elena Peninsula and its offshore continuation.

\subsubsection{Ancón-Pacoa Area}

The Pacoa-1 borehole penetrated early to middle Eocene sequences and reached the Late Cretaceous Santa Elena Formation (Figures 6 and 7). A series of continuous high-amplitude reflections concordant with the top of the Santa Elena Formation are present locally across the onshore Santa Elena High (Figure 7a). This package of high-amplitude reflections was tracked to guide the interpretation of acoustic basement and 
infer its likely structural control on the Santa Elena High configuration. These reflections are observed farther to the south across the Ancón Field and offshore along the continuation of the Santa Elena Peninsula, where well correlation and seismic profiles show a deepening of the Cretaceous units toward the south (Figure 6).

Along a NE-SW seismic profile across the Pacoa Field, the basement-associated continuous reflections are overlain discordantly by folded structures of possible early Eocene age (Figure 7a). Between the two folded structures, a deformed area with steeply dipping reflectors is present and strikes NW-SE. This structure outcrops north of the Pacoa oil field near the coastline (Figure 5d). On seismic line GS-10, which is perpendicular to GS-5 (Figure 7b), parallel slightly folded reflections dip to the southeast, where they are interrupted and apparently overthrust by older rocks. Borehole America-1 (Figure 7b) penetrated Paleocene rocks that are probably thrusted over early Eocene rocks.

Surfaces $\mathrm{U} 1$ and $\mathrm{U} 2$ are characterized by increases in velocity and are clearly defined in borehole B2-ANX1$1 \mathrm{X}$ (at a depth of 400 and $700 \mathrm{~m}$, respectively; Figure 6). The stratigraphic sequences deposited above the U2 unconformity are exposed along the coastal cliffs in the Ancón region, north of borehole B2-ANX1-1X (Figure 4) and have been dated paleontologically and radiometrically as early (?) to middle Eocene (Ordoñez, 1995; Witt et al., 2019). We can link the surface exposures of the Ancón Group to the parallel and subparallel seismic facies above unconformity U2 observed on the seismic profile of Figure 7c. The major unconformity (U2) appears to be intensified near locally deformed structures of the underlying Azúcar Formation, which disrupt the parallelism of the reflections observed elsewhere and suggest syntectonic sedimentation in the basal part of the early-middle Eocene Ancón Group. The lateral changes of the sedimentary facies along the coastal cliffs in the Ancón area (Figure 5e) and the chaotic and downlapping reflections onto unconformity U2 (Figure 7c) may indicate localized syntectonic sedimentation for the area.

The basement-associated continuous reflections observed in Figure 7 show a general shallow position across the Ancón-Pacoa area, where exposures of the Late Cretaceous Santa Elena Formation have been reported previously (Figure 5a, Jaillard et al., 1995). Figure 5b shows the Late Cretaceous Santa Elena Formation overlain unconformably by the Paleocene Azúcar Formation, the boundary of which is poorly defined on seismic profiles farther to the south on the offshore continuation of the Santa Elena High (Figure 8).

\subsubsection{South of Playas}

South of the Ancón-Pacoa area along the extension of the Santa Elena High, a series of structural highs are observed in several seismic profiles. Exploration boreholes Playas- 1 and Golfo- 1 targeted the folded structures as shown in Figures 4 and 8. The seismic profile in Figure 8a shows a stratigraphic gap at the position of Playas-1, passing from thin Quaternary deposits into the Paleocene Azúcar Formation. Along the western limb of the Playas structure, a thick ( $2 \mathrm{~s}$ two-way traveltime) series of parallel to subparallel reflections overlie the major unconformity U1 with an apparent progradation and thickening of this interval (Figure 8a). This thick package is divided into two intervals: the lower one characterized by rapidly varying dipping reflections that are apparently affected by the underlying structure, and the upper interval defined by minor dip changes and more parallel reflections. Unconformity U2 is located between these two sequences (Figure 8). Both sequences conform the early-middle Eocene sequence, which is characterized by parallel to subparallel seismic facies (distorted around structural highs) and small normal faulting displacements.

Figure $8 \mathrm{~b}$ shows a NW-SE-oriented seismic section perpendicular to the seismic profile described previously, which shows the transition toward the Gulf of Guayaquil basin by deepening of the Santa Elena High. The seismic reflections underlying the major unconformity (U1) are chaotic with varying dip directions, which were probably caused by significant deformation. In addition, a series of near vertical structures, which are interpreted as strike-slip faults (F1 and F2) and are oriented ENE-WSW, appears to segment the Santa Elena High possibly through lateral transfer fault ramps (Figure $4 \mathrm{~b}$ ). The apparent onshore continuation of these structures appears to coincide with outcropping structures; the vertically dipping layers of the Azúcar Formation (Figure 5c) at the location of the Playas outcrop (see location in Figure 4) well appear to coincide with the possible northward extension of fault F1 (Figure 4). A comparable situation occurs with fault F2, which has similar characteristics to F1; it appears to extend onshore and coincides with the location of the Chanduy Hills (Figure 4). There is an apparent direct link between the subsurface structures interpreted offshore and those observed onshore as shown in Figure 4. 

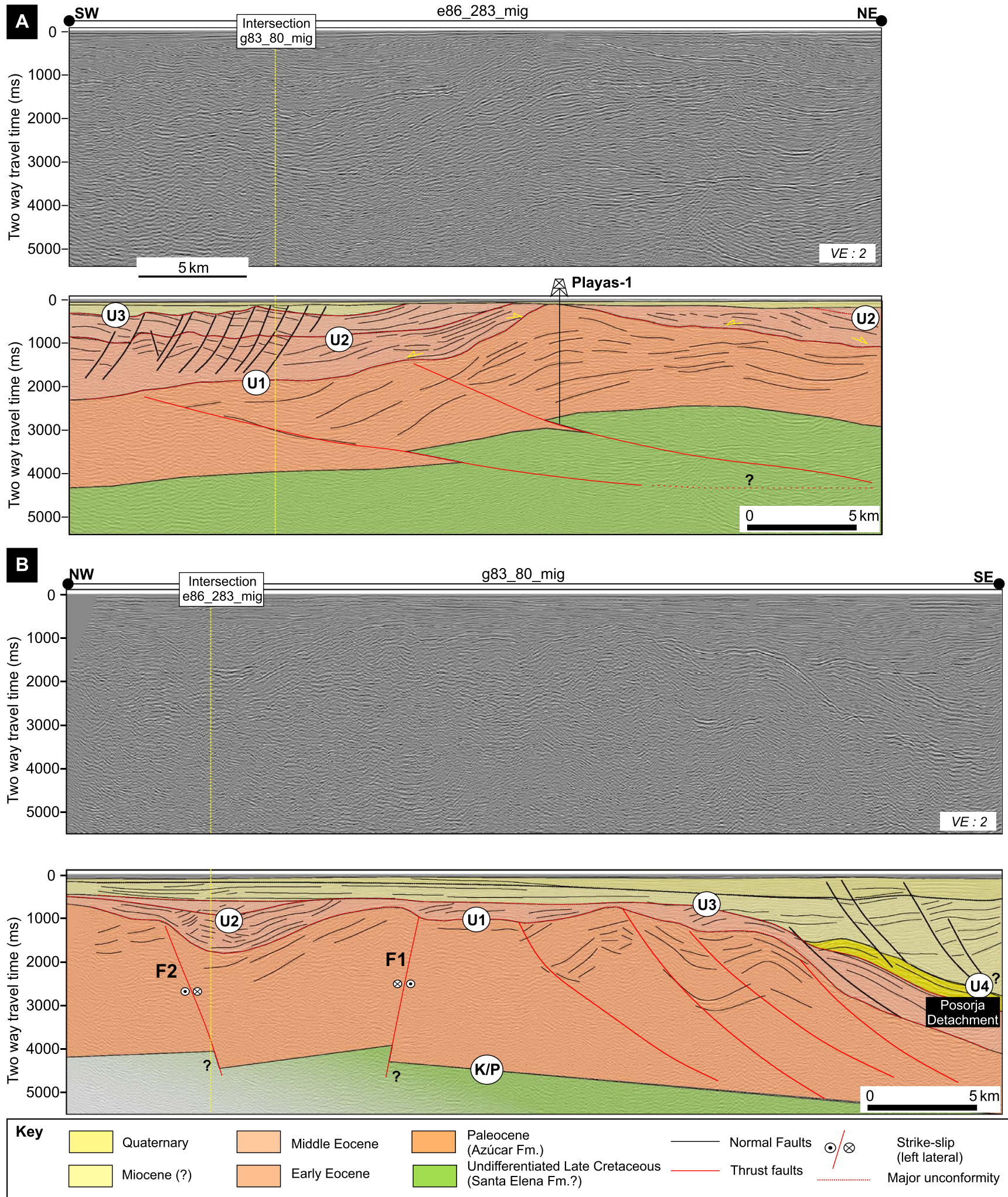

Figure 8. (a) NE-SW composite seismic profile, located south of the Playas outcrops location. A folded structure is observed with seaward dipping layers overlying a strong amplitude erosional event, associated to the main unconformity U1. Playas-1 was drilled on top of the structure founding a very thin Eocene sedimentary sequence. Highly dipping reflections underneath the unconformity U1 are associated to sequences from the Paleocene Azúcar Formation. (b) NW-SE composite seismic profile highlighting lateral ramp structures sealed by major unconformity U3. Toward the south, the Santa Elena High dips southward, affected by a series of low-angle faults conforming the Posorja detachment. 

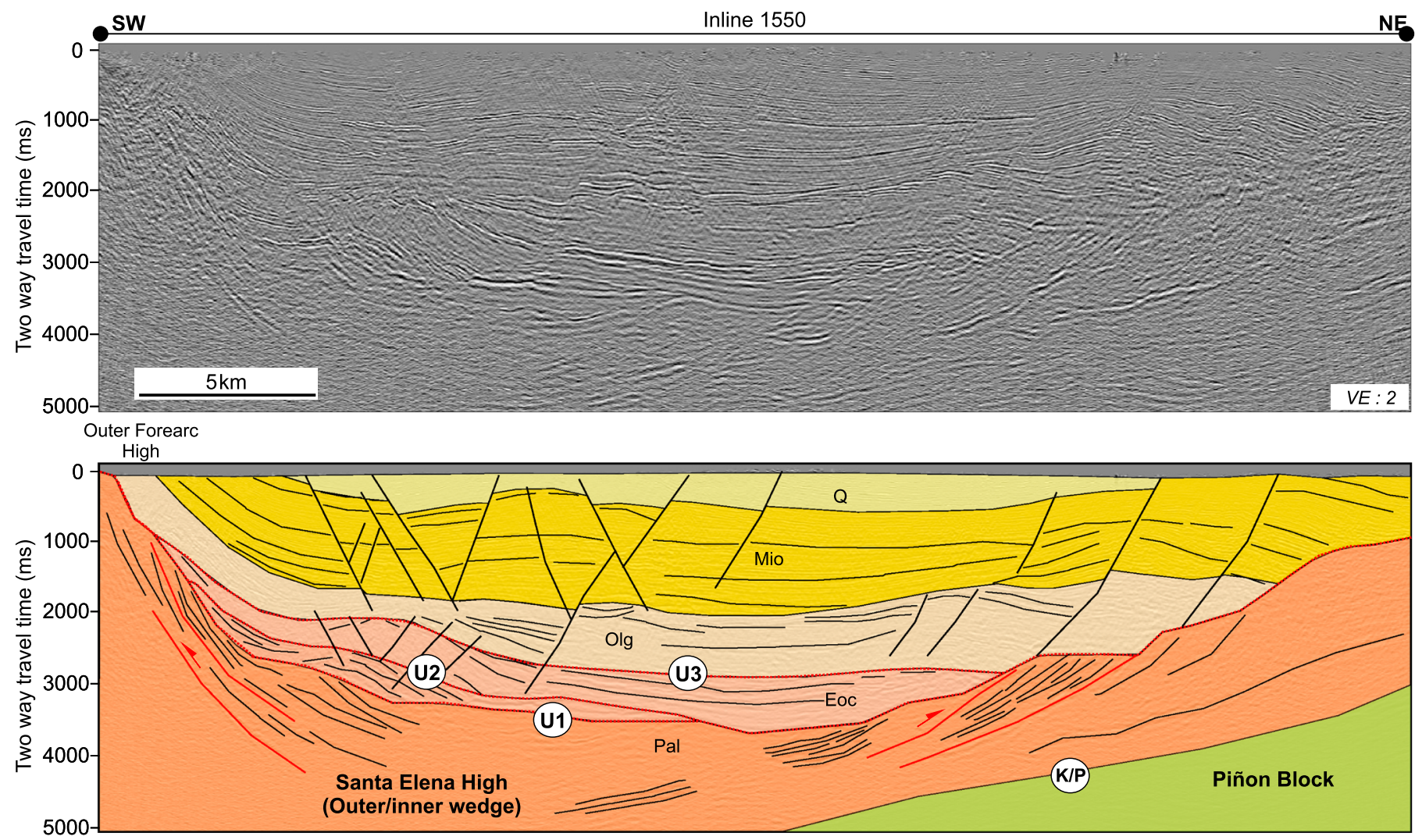

\begin{tabular}{|c|c|c|c|c|c|}
\hline Key & $\begin{array}{l}\text { Quaternary } \\
\text { Neogene }\end{array}$ & $\begin{array}{l}\text { Oligocene } \\
\text { Zapotal fm }\end{array}$ & $\begin{array}{l}\text { Middle Eocene } \\
\text { Early Eocene }\end{array}$ & $\begin{array}{l}\text { Paleocene } \\
\text { (Azúcar Fm.) } \\
\text { Undifferentiated Late Cretaceous } \\
\text { (Santa Elena Fm.?) }\end{array}$ & $\begin{array}{l}\text { Normal Faults } \\
\text { Thrust faults }\end{array}$ \\
\hline
\end{tabular}

Figure 9. Time migrated seismic (Inline 1550) across the Progreso basin. Toward the SW, high dipping reflections coincide with outcropping sequences of the Azúcar Formation along the Estancia Hills (Figure 4). Unconformity U3 seems to mark the uplift and erosion of the Eocene Ancón Group, and deposition of the coarse sediments from the Oligocene Zapotal Fm, toward the Progreso basin.

\subsection{Progreso Basin}

A seismic inline (derived from a 3D cube; Figure 9) shows the underlying geological units of the Progreso basin. Toward the NE, possible SW dipping acoustic basement reflections represent undifferentiated Late Cretaceous volcanoclastic sequences of the Cayo to Guayaquil Formations. Overlying this unit, a series of high-amplitude and steep reflections dipping in different directions (below unconformity U1/U2) may indicate increasing degrees of deformation toward the SW. Similar reflection packages with lower dip angles are present to the NE. These reflection packages are clearly truncated by an erosional surface (coincident with the U1/U2 unconformity), which may mark the limit of an active deformational phase during the Paleocene. Overlying the major and semiregional unconformity (U1), steeply dipping reflections with chaotic to subparallel seismic characteristics are attributed to early-middle Eocene deposits of the Ancón Group. Toward the center of the basin, the reflections become subparallel and onlap onto the underlying Paleocene highly deformed area.

Up-section, laterally varying high-amplitude reflections may represent the Oligocene shallow water to continental deposits of the Zapotal Formation, which are probably interbedded with silty deposits (lowamplitude reflection seismic facies). The Zapotal Formation consists of coarse sediments derived from the emerged and subaerially exposed Santa Elena High (Figure 3).

Less deformed reflections characterized by extensional tectonics overlie the Oligocene series of the Zapotal Formation. This seismic stratigraphic unit corresponds to Miocene sequences that, based on outcrop 

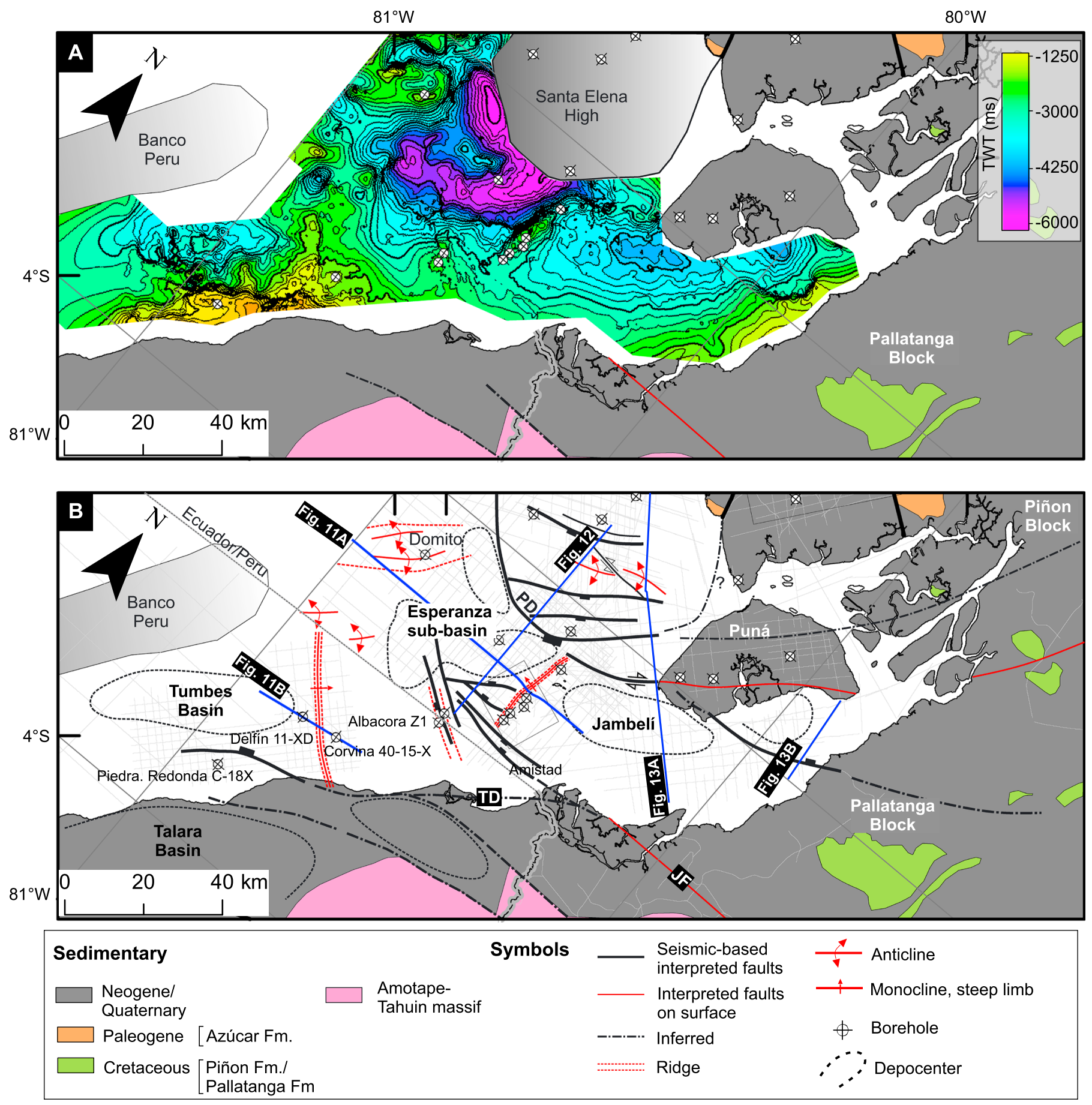

Figure 10. (a) Two-way travel time (TWT) map for the early-middle Miocene unconformity (U4). (b) Structural map showing the main lineaments identified from seismic profiles and their inferred onshore continuation. Notice the local extend of the Santa Elena High with respect to the Gulf of Guayaquil-Tumbes basin. $\mathrm{JF}=$ Jubones fault; $\mathrm{PD}=$ Posorja detachment; $\mathrm{TD}=$ Tumbes detachment.

exposures, are described as shallow marine deposits (Benitez, 1995). On the seismic profile shown in Figure 9, this unit maintains a relatively equal thickness in the direction perpendicular to the basin axis and expands slightly southward (Benitez, 1995), suggesting a very low subsidence rate or deformation during the Miocene in this area. 

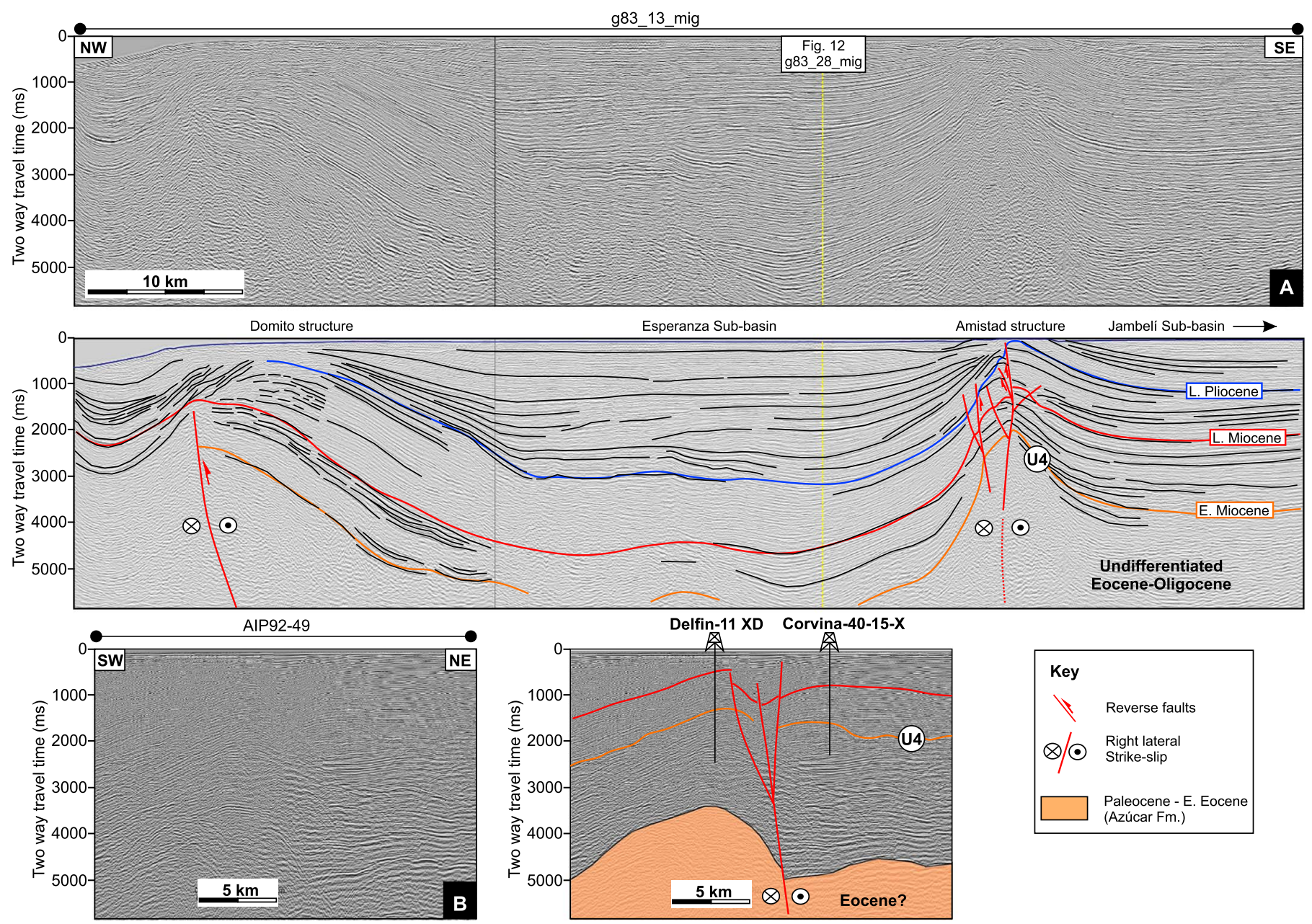

Figure 11. (a) Seismic profile across the Amistad and Domino antiforms showing the Esperanza sub-basin in between. (b) SW-NE profile across the Corvina structure, a structure likely to be connected to the Domito fold trend farther to the north (Figure 10).

\subsection{Gulf of Guayaquil-Tumbes Basin}

From east to west, the Gulf of Guayaquil-Tumbes basin is defined by a NNW dipping monoclinal structure and can be subdivided into a series of blocks bounded by approximately E-W striking and north dipping normal faults (Figure 10). The crustal fault blocks that apparently fragmented the Amotape-Tahuin massif, and subdivide the Tumbes from the Talara basin in NW Peru (Figure 1), appear to extend offshore as observed in Figure 10a. Moving to the east, the offshore extension of the Jubones fault is diffuse in the Gulf of Guayaquil, marking an apparent boundary between the Tumbes and Jambelí sub-basins (Figure 10). At the eastern offshore limit of the Jambelí area, a similar expression of these crustal lineaments is identified in Figure 10a. This steep fault system seems to extend onshore into the Pallatanga Block (Figure 10b) and may be genetically related to the tectonic process of block fragmentation due to shear lateral movements, as those reported in NW Peru.

Tight anticlinal structures separate the shallower Tumbes and Jambelí sub-basins from the deep Esperanza sub-basin (Figure 11a). Toward the eastern limit of the Tumbes sub-basin, an antiform forms the Corvina structure, which is apparently affected by strike-slip movements (Figure 11b). Industrial boreholes in the Corvina and Delfín hydrocarbon fields (Figure 11b) reached late Oligocene/early Miocene sequences without penetrating the deeper high-amplitude reflections, which may correspond to the underlying Eocene sequences of the Talara basin (lower wedge according to Espurt et al., 2017).

Farther to the east, the Amistad antiform structure defines the eastern boundary of the deepest Esperanza sub-basin. Figure 11a shows the Amistad and Domito antiforms separating the deepest Esperanza sub- 

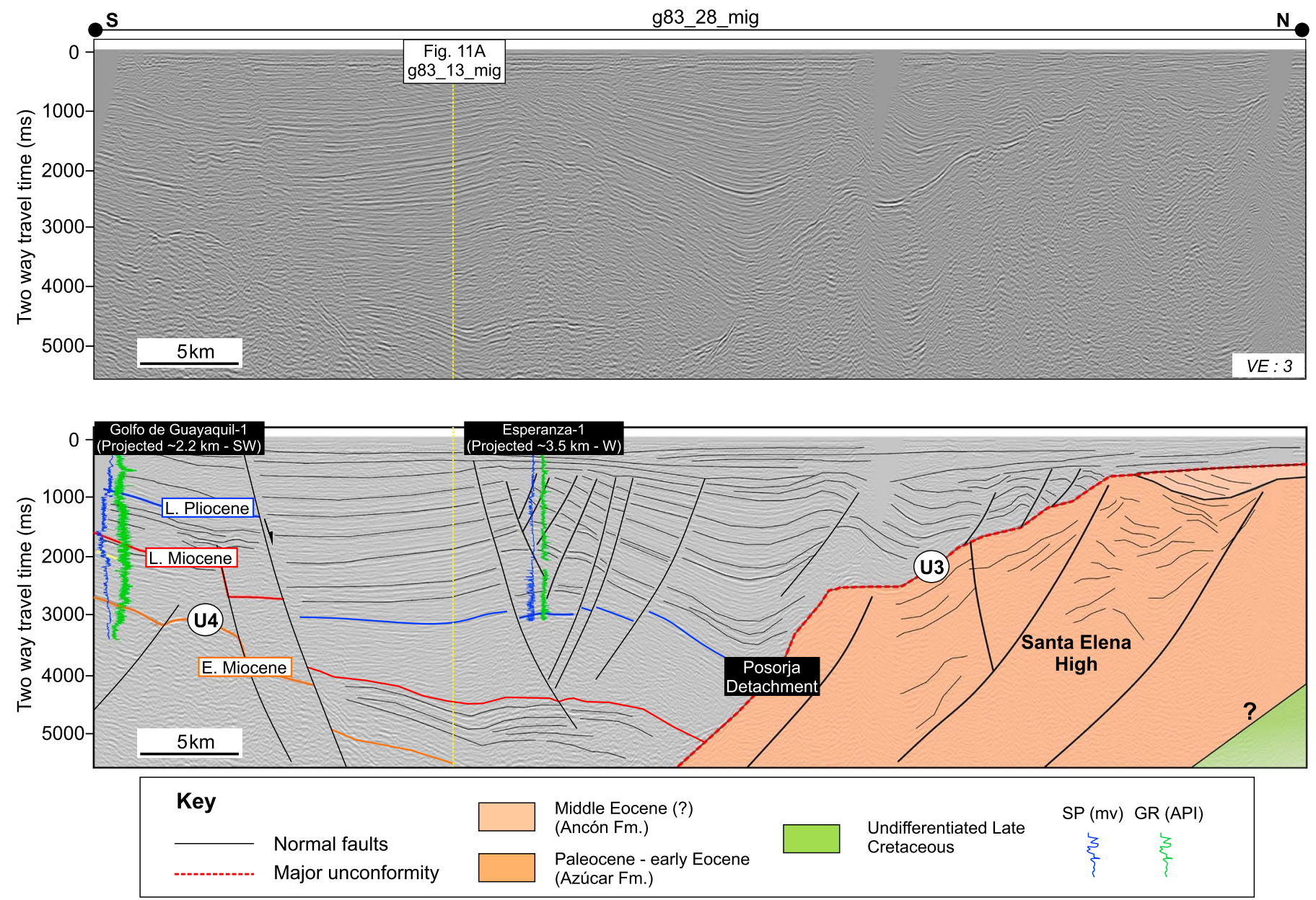

Figure 12. Interpreted seismic section across the Gulf of Guayaquil basin and the Santa Elena High. Toward the south, a series of Miocene sequences are penetrated by the Gulf of Guayaquil-1 borehole. At the center, the Esperanza sub basin, a depression mark by a thick succession of Plio-Quaternary sediments.

basin from the Jambelí sub-basin. There is apparent thinning of the late Miocene interval, although the seismic quality precludes studying this issue properly. A seismic profile across the deepest part of the Gulf of Guayaquil-Tumbes basin shows a thick succession of Plio-Quaternary sediments (Figure 12). The northern limit of these successions is defined by the Posorja detachment (Deniaud et al., 1999; Witt \& Bourgois, 2010) (Figure 12). Based on our seismic interpretation and the results from the Esperanza-1 borehole, we estimate a thick Quaternary sedimentary succession (at least 3.5- to 5-km thick) in the main depocenter area, south of the Posorja detachment (Figure 12). This seismic profile shows an anticlinal structure characterized by crestal extension, oriented NE-SW, at the center of the Esperanza sub-basin. These extensional faults dipping toward the center of the structure are apparently layer bounded along the top of the late Miocene surface (in red), suggesting that the structure is not basement controlled and thus formed during the Plio-Quaternary time interval (Figure 12).

An industrial borehole located in the Gulf of Guayaquil (Gulf of Guayaquil-1, Figure 12) penetrated early Miocene and possibly late Oligocene deposits. Although the seismic profile in Figure 12 shows deeper reflections, we suspect that those reflections correspond to Oligocene and possibly older sequences. Following these deepest reflections from the location of Gulf of Guayaquil-1 toward the east, a significant pinch-out of the sequences is observed in Figure 13. This NW-SE-oriented seismic profile across Puná Island reveals early Miocene sequences above the inferred Late Cretaceous acoustic basement (characterized by chaotic and varying dipping direction reflections). To the north, the structural styles are different, transitioning from a monoclinal and north dipping structure into a complex area with tightly folded structures similar to those 

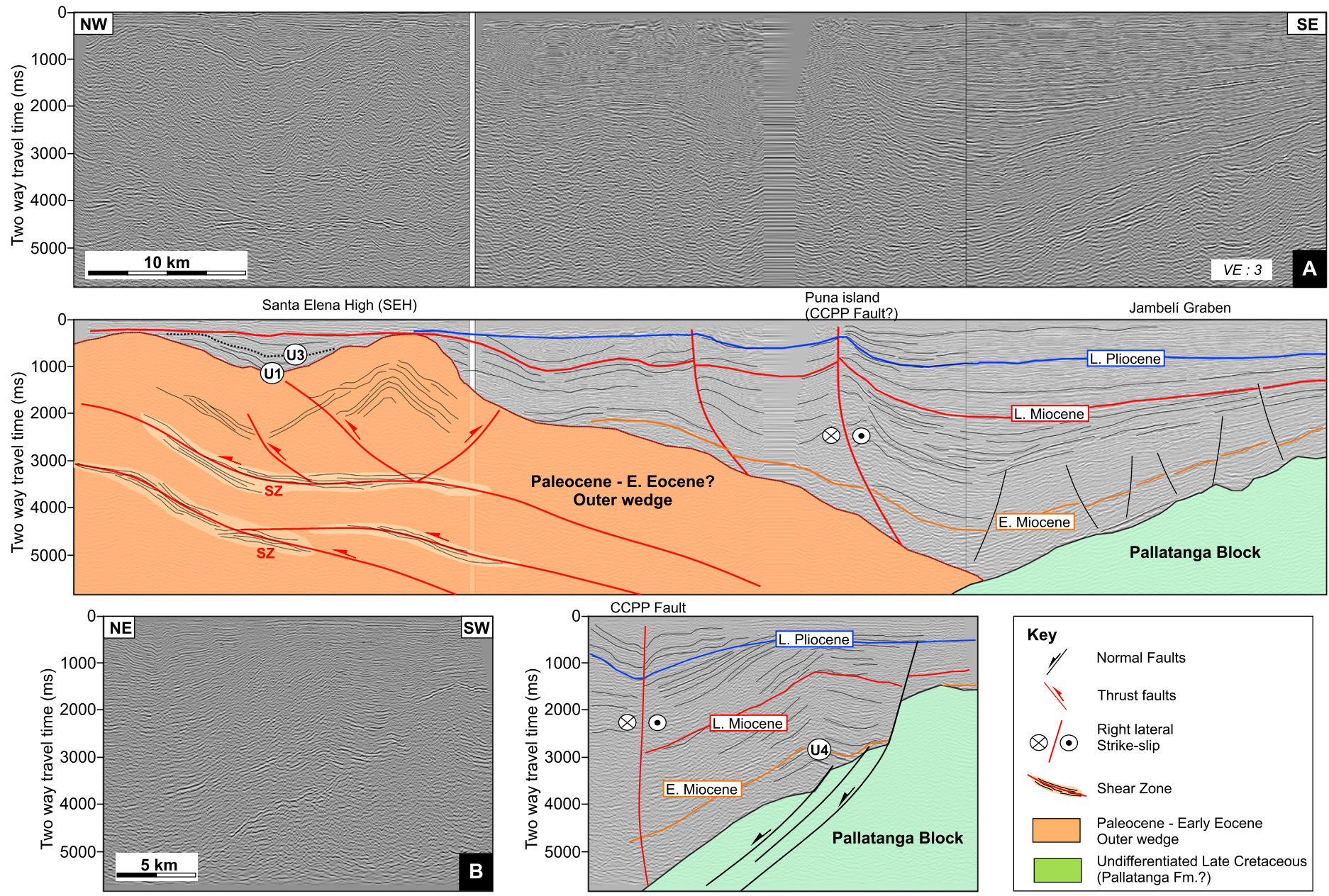

Figure 13. (a) NW-SE composite seismic profile across the Jambelí area and the Puna Island, and into the southern part of Santa Elena High. Toward the south, a series of siliciclastic sequences of Miocene to Quaternary age are correlated and tied to boreholes located farther west. The sedimentary successions thin toward the south and apparently onlap onto Pallatanga Block. The series of high-amplitude reflections associated to shear zones (SZ) may represent the high deformation related to the formation of the Santa Elena High. (b) Seismic section farther to the northeast, which shows the possible displacement of the underlying Pallatanga Block occurring since early-middle Miocene.

observed in Figure 8b. The series of thrust faults and shear zones interpreted in Figure 13 probably root at the transition between the Santa Elena High and crustal basement rocks attributed to the Pallatanga Block.

The surface expression of the tightly folded structure observed near the transition from the southern limit of the Santa Elena High and possibly northern extend of the Pallatanga Block is defined by the Puná Island, which is located a few kilometers to the east of the profile (Figure 10). A fault analysis at the surface on Puná Island characterized this deformation as a positive flower structure (Dumont et al., 2005).

\section{Discussion}

Two major acoustic basement units were mainly identified in this study: (1) a westward extension of the Pallatanga Block that interacts to the west with the Amotape-Tahuin massif, and (2) highly deformed Late Cretaceous sediments that accreted onto the CLIP crustal fragments. Both basement domains are characterized by different structural expressions and different seismic facies. This study defines at least four tectonostratigraphic units (Figure 3) overlying these inferred acoustic basement units: (1) a highly deformed Paleocene sequence, (2) an early to middle Eocene sedimentary succession that accumulated on the slope segment of unit 1; (3) an Oligocene to late Miocene sequence that was deposited in a transtensional 

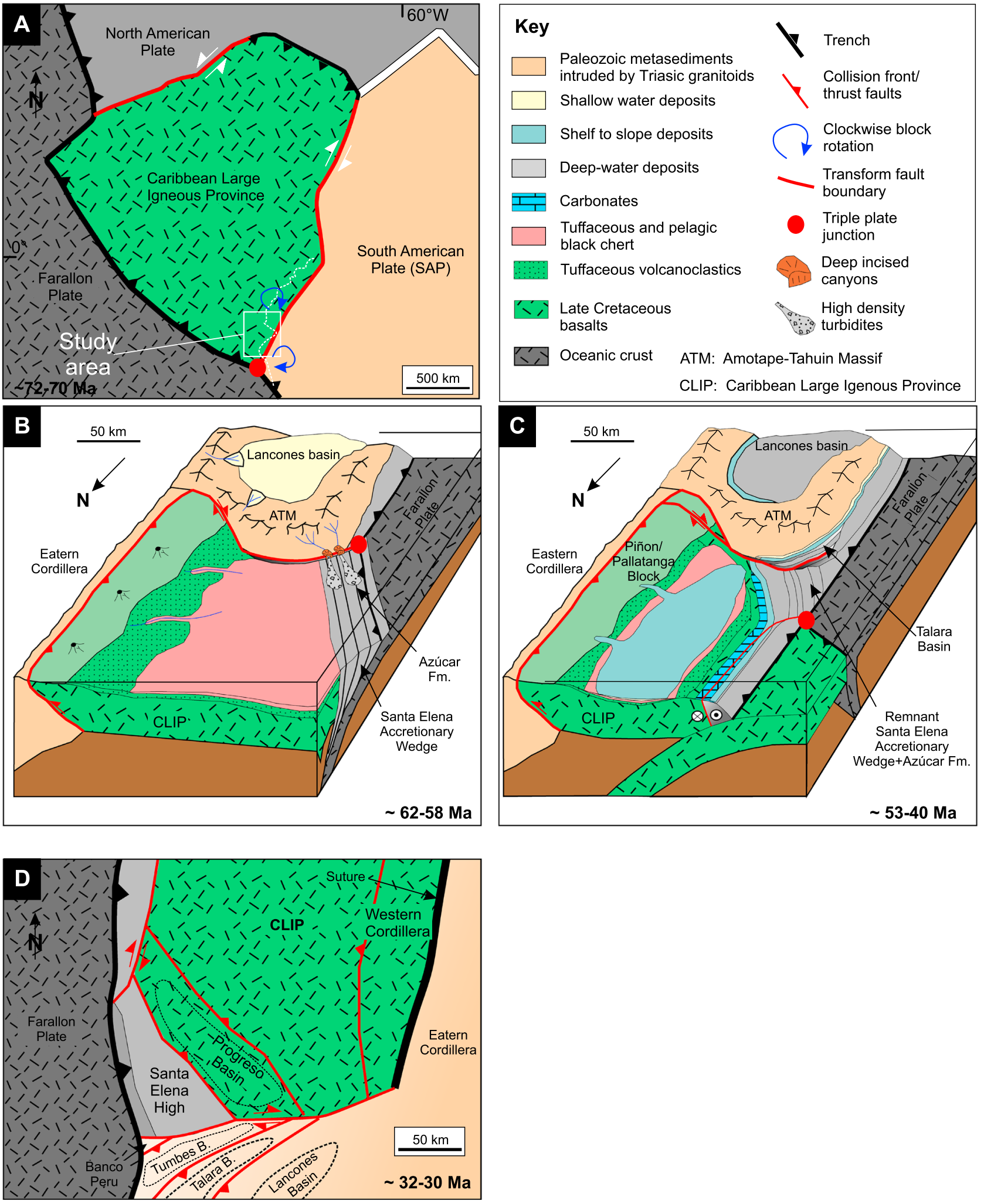

Figure 14. Series of sketches showing the proposed tectonic evolution of SW Ecuador and NW Peru. (a) A possible scenario of accretion of the CLIP against the South American plate, showing the possible location of a triple plate junction (modified after Boschman et al., 2014). (b) The deposition of the Paleocene Azúcar Formation, over a Late Cretaceous accretionary wedge. (c) The reestablishment of a stable subduction system with trench retreat and development of the Talara basin in NW Peru. (d) Simplified sketch highlighting the spatial relationship of the main tectonic elements postaccretionary phase at 32-30 Ma. Notice the development of the Progreso basin limited to the west by the Santa Elena High. 
setting in the Gulf of Guayaquil-Tumbes area and as a forearc sensu stricto setting in the Progreso basin; and (4) a thick Plio-Quaternary sedimentary sequence within an subsiding depocenter (Esperanza sub-basin, Figure 2). Units 1 and 2 are mainly identified across the Santa Elena High, and units 3 and 4 are mainly identified in the Gulf of Guayaquil-Tumbes and Progreso area; unit 2 is also possibly present in the Gulf of Guayaquil-Tumbes area.

\subsection{Possible Effects on the Margin Following the Arrival of the CLIP}

Following the results presented by Moresi et al. (2014) and Vogt and Gerya (2014) from numerical models of the dynamic of oceanic plateau accretion and subduction, we discuss the collision stage of the CLIP and its possible effects on the margin that led to the following stages of margin instability (stage 2) to reinitiation of a stable subduction system (stage 3) discussed within the next section.

Thermochronological indications suggest significant cooling and exhumation rates along the eastern Cordillera (Spikings et al., 2010) at circa 73-70 Ma, which mark the onset of the collision of the CLIP with the proto-NW South American margin in Ecuador (Vallejo et al., 2009). However, south of the study area, Jaillard et al. (1999) report that the Lancones basin underwent a phase of deformation marked by compressional tectonism, dextral shear movements, and erosion of the Amotape-Tahuin massif during Coniacian to Santonian times. This tectonic phase may represent an early interaction of the CLIP with the margin farther south in NW Peru. The transition from a stable and subsiding Lancones basin during the LateEarly Cretaceous to an unstable forearc with trenchward uplift of the Amotape-Tahuin massif and block rotations (Mourier et al., 1988) may be directly associated with an unstable plate configuration that was possibly created by the interaction between the leading edge/southern limit of the CLIP, the subducting oceanic Farallon plate, and the NW South American plate (Figure 14a) in a scenario similar to those predicted by numerical modeling (Moresi et al., 2014; Vogt \& Gerya, 2014). If the plate instability was linked to the arrival of the CLIP at the margin, its collision may have occurred diachronically from ConiacianSantonian times in NW Peru to Maastrichtian times in Ecuador. This indentation process of the CLIP to the NW South American margin may have exerted a torque on the overriding plate (Wallace et al., 2009, 2005), which may have caused significant margin variations across the transform fault boundary between the southern limit of the CLIP and the NW South American plates. It has been recognized that oceanic plateau-trench collisions can strongly influence the shape of the trench; depending on the density of the plateau, this may cause significant trench retreat and advances in the region surrounding the plateau (Mason et al., 2010).

Therefore, we propose that the CLIP played a key role in defining a tectonic framework for further Cenozoic development of the forearc region, including crustal fragmentation, block rotations, and backstop effects in both SW Ecuador and NW Peru.

\subsection{From an Unstable to a Stable Margin (Paleocene-Eocene Stage)}

Surface exposures of the Azúcar Formation provide evidence of the first sialic-derived deposits in SW Ecuador, after the accretion of the CLIP. The sedimentary facies, architectural elements, and paleocurrent indicators (Benitez, 1995; Moreno, 1983), along with heavy mineral provenance analysis, suggest a southern provenance of the Azúcar Formation, probably from the Amotape-Tahuin massif; this model was recently corroborated by Witt et al. (2017). A problematic aspect of the Paleocene series is its local distribution. The Paleocene series (60-55 Ma) are observed neither north of the Chongón-Colonche Hills nor in NW Peru, where the oldest sedimentary rocks above the basement have ages of 54-53 Ma (Witt et al., 2018). The depositional record and location of the Paleocene series with respect to the continental margin suggest a different configuration of the margin south of the Chongón-Colonche Hills, which was possibly controlled by the remnant of an ancient subduction system related to the previous deformation of the Santa Elena Formation (Figure 14b). Although difficult to define in seismic data and on the field, the vergence of the main structures is most likely to the ENE, although local structures, such as those in the Playas area, may be related to secondary structures like accommodation faults or oblique ramps. Furthermore, our integration of borehole, seismic, and outcrop data throughout the Santa Elena High shows that the Azúcar Formation grades to the north into fine and deeper water facies that apparently pinch out across the Pacoa area (Figure 6). 
The relatively local character of the deformed series of the Azúcar Formation (approximately 100-150 km in extent) prevents defining the unit as part of a regional accretionary prism; instead, a more local model is proposed in which the Azúcar Formation was deposited across a margin offset resulting from the instability of a triple plate junction (Figure 14b).

Subsequent basin reconfiguration and forearc uplift within a stable and reestablished margin may have taken place following the accretion of remnants from the ancient Santa Elena accretionary wedge and the overlying Paleocene deposits, which is currently called the Santa Elena High. Along the Chongón Colonche Hills and farther north, early to middle Eocene carbonaceous deposits of the San Mateo Formation and equivalents were unconformably deposited on Late Cretaceous volcanoclastic deposits of the Cayo Formation (Jaillard et al., 1995), defining the limit of the Paleocene depocenter and a major shift in the sediment source at this time (Figure 14c).

South of the Chongón-Colonche Hills, upper slope to deepwater slope sandstones of the Ancón Group overlie the highly deformed Azúcar Formation or sit directly on the Late Cretaceous Santa Elena Formation. The Ancón Group was deposited unconformably across a combined Late Paleocene-early Eocene surface (U2, Figure 6). A clear structural and stratigraphic change is observed across the boundary between the Azúcar Formation and the Ancón Group, as revealed by outcrop and seismic data (Figures 5 and 8). This change has been proposed to be related to the emergence of the Santa Elena High following the collision of the Cayo Arc during the Late Paleocene (Jaillard et al., 1995). However, the Cayo Arc had already accreted onto the margin prior to the deposition of the Azúcar Formation (Van Melle et al., 2008). Furthermore, both the basal part of the Ancón Group and the Azúcar Formations are characterized by deepwater facies, precluding the idea of subaerial exposure of the Late Paleocene Azúcar Formation. The Ancón Group is marked by extensional deformation that is most likely related to gravitational instability. Thus, we propose that the deformation of the Azúcar Formation is related to an accretionary event, very likely through reactivation of the ancient Santa Elena accretionary wedge (Figure 14b), during Late Paleocene-early Eocene with quiescence during the deposition of the middle Eocene Ancón Group (Figure 14c), which represents the switch from a trench jump (stage 2) to the reinitiation of a stable subduction system (stage 3) farther to the west. This event is correlated with the end of the cooling and exhumation phase events recorded in the Amotape-Tahuin massif and is highly coincident with the end of sedimentation of the Azúcar Formation at $\sim 55 \mathrm{Ma}$ (Witt et al., 2019).

\subsection{Preservation of the Santa Elena Accretionary Wedge in SW Ecuador}

The underlying mechanism that led to the localization of the thick wedge related to the Azúcar Formation may be related to the resulting margin configuration after the collision and indentation of the CLIP (Figure 14), possibly causing a tear-faulted subducting slab that was able to accommodate thick Paleocene sedimentary sequences. Similar observations of a deepening and thickening wedge oblique to the convergence direction that was controlled by a physical boundary at one edge (in our case, this boundary is represented by the Amotape-Tahuin massif) have been reported in the Sumatra, southern Ryukyu, and Hikurangi trenches (Heuret et al., 2012; Malatesta et al., 2013).

Furthermore, the location of the Santa Elena High compared to the autochthonous Amotape-Tahuin massif and the allochthonous Piñon Block cannot be disregarded. We suggest that variations in the material strengths of the different crustal blocks involved in the region may have played a significant role in the location and orientation of the Santa Elena High and in the formation of the Progreso basin. Therefore, we propose that the Piñon Block may have acted as a backstop since the Early Paleocene under an oblique subduction regime. The interaction between the ancient Santa Elena accretionary wedge and the Piñon Block resulted in the formation of an outer wedge, known as the Santa Elena High. The early outer wedge configuration may have developed a west to northwest dipping slope along the seaward margin, where gravity-driven sediments from the middle Eocene Ancón Group were deposited over unconformity U2, as observed in seismic profiles and the well correlation presented within this study (Figure 6). During the Oligocene, a second major uplift of the accretionary prism may have formed the restricted Progreso forearc basin, which is indicated by the deposition of the immature sediments of the Zapotal Formation along the La Cruz fault (Witt et al., 2019). This continuous uplift of the Santa Elena High, which played a key role in the forearc basin evolution, may have been possible due to the inherited margin configuration, which allowed the accumulation of significant quantities of sediments that prevented an erosional 
regime of subduction beneath the Santa Elena High and instead created a local outer forearc high since the Oligocene.

\subsection{Development of the Progreso and Gulf of Guayaquil-Tumbes Basins}

Following the deposition of the middle Eocene Ancón Group, a major uplift of the entire forearc region occurred in the Oligocene. This is supported by the coarse-grained and immature sediments of the Zapotal Formation that were deposited at 32-30 Ma (Figure 3, Witt et al., 2019) along the axis of the restricted Progreso basin. Similar conditions occurred in the Tumbes and Talara depocenters, where coarse-grained fluvio-deltaic Oligocene sequences have been identified in the field and in the subsurface (Mancora Formation; Figure 3, Espurt et al., 2017; Fernández et al., 2005). The deposition of continental coarse-grained sediments marked the first major subaerial unconformity in the region, which is defined in this study as the U3 unconformity (Figures 6 and 8). This may represent the principal evidence of a transition from trench to forearc deposition due to the development of outer forearc highs, such as the Santa Elena High in SW Ecuador and possibly Banco Peru in NW Peru.

The forearc region within the study area is underlain by different crustal units of oceanic and continental affinities; thus, a focus on identifying the suture appears to be critical. The quasi-perpendicular relationship between the orientations of the Progreso and Gulf of Guayaquil-Tumbes basin axes (Figure 14d) suggests that different underlying processes controlled their structural development.

The suture between the remnants of the CLIP and the South American plate is well documented along the western and eastern Cordilleras (Alvarado et al., 2016) but has been poorly constrained in the Gulf of Guayaquil. Its location is still uncertain and debated (Aizprua et al., 2017). Nevertheless, a unique vestige of the contact between these two crustal blocks occurs at the Jubones fault (Figures 1 and 10), which is the closest location of the suture to the offshore Gulf of Guayaquil. The offshore continuation of this structure appears to be deeply buried and below the depth of investigation of the current seismic profiles. Nevertheless, our integration across the Jambelí, Gulf of Guayaquil, and NW Peru (Figure 10) allowed us to point out three key elements that may support the location of the suture across the Gulf of Guayaquil: (1) a northwest dipping surface, which may represent the offshore continuation of the oceanic crustal rocks of the Pallatanga Block (age equivalent to the Piñon Block) north of the Jubones fault (Figure 13); (2) shallow expressions of potentially reactivated or basement-controlled normal faults (potentially along the suture) with diffuse patterns and E-W orientations (Figure 10); and (3) continental crustal fault-bounded blocks observed at the surface south of the Jubones fault, which delimit the forearc depocenters in NW Peru (Figures 1 and 10).

Our model proposes that during the initial stage of forearc development, the Tumbes and Progreso basins formed an embayment with a sea inlet possibly located between the Banco Peru and the Santa Elena High, an area that is coincident with the change in strike of these two structural highs and may coincide with the position of the transform boundary (Figure 14d). The Jubones fault at this stage is inferred to have played a significant role in the development of the forearc, possibly by acting as a major conduit of sediments toward the basin.

A second stage of forearc basin development is inferred to have taken place by the late early to middle Miocene ( $15 \mathrm{Ma}$ ) and may represent the first vestige of the opening of the Gulf of Guayaquil. Seismic profiles on the eastern side of the Tumbes sub-basin and across the Jambelí sub-basin show two key elements: (1) an erosional event along the eastern border of the Tumbes basin (unconformity U4, Figure 11b), which may extend farther to the southeast and link to the inferred Tumbes detachment (Figure 10), and (2) a possible fault jump from the Jubones fault to the Jambelí detachment via further fragmentation of the underlying Pallatanga crustal block (Figures 10 and 13b), producing the local late-early Miocene erosion (U4, Figure 10a). Our analysis also suggests that the Santa Elena High outer wedge may have controlled the development of both the Progreso and Gulf of Guayaquil basins through the development of an outer forearc high, which generated restricted conditions, especially in the Progreso basin (32-30 Ma, Witt et al., 2019), and acted as the northern bounding block for the Gulf of Guayaquil area (Figures 12 and 13). An interaction between the Santa Elena High and the north dipping successions overlying the Pallatanga Block may have resulted in local transpressional movements, which possibly gave rise to the development of some of the ridges and the Puná Island observed in Figure 10. This interaction may correspond to an initial stage of tectonic escape of the North Andean Sliver. 


\section{Conclusions}

In this study, we used an integrated and multidisciplinary approach with different scales of observations to propose an updated tectonic model for SW Ecuador and NW Peru. The structural interpretation linking onshore and offshore structures allowed us to delineate an ancient and preserved Late CretaceousPaleocene accretionary wedge that may have formed at a concave margin at the trailing edge of the CLIP along the Northern Andes (Figure 14).

The process that led to a concave margin during the Late Cretaceous is uncertain, but we propose that the southern limit of the CLIP may have created an unstable triple plate junction with the oceanic Farallon plate and the South American plate. Plate instability may have resulted in a tearing of the Piñon Block creating a localized depocenter, NW of the Amotape-Tahuin massif, where deposition of the Paleocene Azúcar Formation overlying the Santa Elena accretionary wedge took place. Plate stability may have been reached by the end of the Eocene, through translation of the junction farther north. A movement that is possibly reflected in NW Peru by sequential trench retreats in both NW Peru and SW Ecuador. This is in agreement with trench retreat and seaward advance of the forearc depocenters proposed in NW Peru by Espurt et al. (2017).

The accretion and preservation of an ancient accretionary wedge along the southern trailing edge of the CLIP, post reestablishment of a stable subduction system, seems to have controlled the postaccretionary forearc basin configuration in the region. Further oblique subduction and strike-slip fault movements along the western edge of the Santa Elena High outer wedge may have taken place, controlling the development of the forearc region. These processes may have led to a strong interaction between the Santa Elena High outer wedge and the crustal sliver of the CLIP, this last one acting as a backstop, and resulting on the development of a local sensu stricto forearc basin (Progreso basin) controlled by development of a local outer forearc high.

The results from this study may represent a natural example of recent numerical models of the dynamic of allochthonous terrane accretion along continental margins (Moresi et al., 2014; Vogt \& Gerya, 2014). Therefore, we propose that the accretion of oceanic plateaus may have had a great impact on the early margin configuration of ancient forearc basins, such as in SW Ecuador and NW Peru, where we found the development of localized but genetically related forearc depocenters.

\section{Acknowledgments}

The authors wish to thank

Petroamazonas EP (Quito, Ecuador) for kindly providing all of the subsurface data used in this study. We are particularly grateful to Marco Rivadeneira for encouraging this study and to the exploration team from Petroamazonas for rewarding discussions about the subsurface geology of the study area. We are in debt to Galo Montenegro for his insights into the geology of SW Ecuador and for fruitful discussions in the field. Associate Editor Federico Rossetti; Reviewers Adrian Pfiffner, James Kellogg, and an anonymous referee, and Journal Editor John Geissman are acknowledged for their thorough review and constructive comments. This research was conducted as part of a Ph.D. thesis by C. Aizprua at the Norwegian University of Sciences and Technology (NTNU) jointly with the University of Lille in France and was supported by funds from Statoil's AKADEMIA agreement (Norway). Schlumberger is thanked for provision of Petrel ${ }^{\circledast}$ for seismic interpretation. The data used for this study are accessible at the NTNU Open Research data repository (https://doi.org/10.18710/ BYZIZX).

\section{References}

Aizprua, C., Witt, C., Bronner, M., Barba, D., \& Johansen, S. E. (2017). Forearc basin structuring and seismicity patterns controlled by a trapped sliver from the Caribbean large igneous province (CLIP): Northern Andes. Paper presented at William Smith meeting 2017; Plate Tectonics at 50, abstract book, Geological Society of London, London, UK.

Aizprua, C., Witt, C., Johansen, S., \& Barba, D. (2019). Replication Data for: Cenozoic stages of forearc evolution following the accretion of a sliver from the Late Cretaceous-Caribbean large igneous province (CLIP): SW Ecuador-NW Peru, edited by S. Norwegian University of and Technology, DataverseNO.

Alvarado, A., Audin, L., Nocquet, J. M., Jaillard, E., Mothes, P., Jarrin, P., et al. (2016). Partitioning of oblique convergence in the Northern Andes subduction zone: Migration history and the present-day boundary of the North Andean sliver in Ecuador. Tectonics, 35, 1048-1065. https://doi.org/10.1002/2016TC004117

Andjić, G., Baumgartner, P. O., \& Baumgartner-Mora, C. (2018). Rapid vertical motions and formation of volcanic arc gaps: Plateau collision recorded in the forearc geological evolution (Costa Rica margin). Basin Research, 30(5), 863-894. https://doi.org/10.1111/ bre. 12284

Aspden, J. A., Fortey, N., Litherland, M., Viteri, F., \& Harrison, S. M. (1992). Regional S-type granites in the Ecuadorian Andes-Possible remnants of the breakup of western Gondwana. Journal of South American Earth Sciences, 6(3), 123-132. https://doi.org/10.1016/08959811(92)90002-G

Beck, M. E. (1983). On the mechanism of tectonic transport in zones of oblique subduction. Tectonophysics, 93(1-2), 1-11. https://doi.org/ 10.1016/0040-1951(83)90230-5

Benitez, S. (1995). Évolution géodynamique de la province côtière sud-équatorienne au Crétacé supérieur-Tertiaire, Université JosephFourier - Grenoble I.

Bosch, D., Gabriele, P., Lapierre, H., Malfere, J.-L., \& Jaillard, E. (2002). Geodynamic significance of the Raspas metamorphic complex (SW Ecuador): Geochemical and isotopic constraints. Tectonophysics, 345(1-4), 83-102. https://doi.org/10.1016/S0040-1951(01)00207-4

Boschman, L. M., van Hinsbergen, D. J. J., Torsvik, T. H., Spakman, W., \& Pindell, J. L. (2014). Kinematic reconstruction of the Caribbean region since the Early Jurassic. Earth-Science Reviews, 138, 102-136. https://doi.org/10.1016/j.earscirev.2014.08.007

Deniaud, Y., Baby, P., Basile, C., Ordonez, M., Montenegro, G., \& Mascle, G. (1999). Opening and tectonic and sedimentary evolution of the Gulf of Guayaquil: Neogene and Quaternary fore-arc basin of the south Ecuadorian Andes. Comptes Rendus de l'Academie des Sciences Series IIA, 328(3), 181-187.

Dickinson, W. R. (2013). Phanerozoic palinspastic reconstructions of Great Basin geotectonics (Nevada-Utah, USA). Geosphere, 9(5), 1384-1396. https://doi.org/10.1130/GES00888.1

Draut, A. E., \& Clift, P. D. (2013). Differential preservation in the geologic record of intraoceanic arc sedimentary and tectonic processes. Earth-Science Reviews, 116, 57-84. https://doi.org/10.1016/j.earscirev.2012.11.003 
Dumont, J. F., Santana, E., \& Vilema, W. (2005). Morphologic evidence of active motion of the Zambapala fault, Gulf of Guayaquil (Ecuador). Geomorphology, 65(3-4), 223-239. https://doi.org/10.1016/j.geomorph.2004.09.003

Egbue, O., \& Kellogg, J. (2010). Pleistocene to present North Andean "escape". Tectonophysics, 489(1-4), 248-257. https://doi.org/10.1016/j. tecto.2010.04.021

Ego, F., Sébrier, M., Lavenu, A., Yepes, H., \& Egues, A. (1996). Quaternary state of stress in the Northern Andes and the restraining bend model for the Ecuadorian Andes. Tectonophysics, 259(1-3), 101-116. https://doi.org/10.1016/0040-1951(95)00075-5

Espurt, N., Brusset, S., Baby, P., Henry, P., Vega, M., Calderon, Y., et al. (2017). Deciphering the Late Cretaceous-Cenozoic structural evolution of the North Peruvian forearc system. Tectonics, 37, 251-282. https://doi.org/10.1002/2017TC004536

Feininger, T. (1987). Allochthonous terranes in the Andes of Ecuador and northwestern Peru. Canadian Journal of Earth Sciences, 24(2), 266-278. https://doi.org/10.1139/e87-028

Feininger, T., \& Seguin, M. K. (1983). Simple Bouguer gravity-anomaly field and the inferred crustal structure of continental Ecuador. Geology, 11(1), 40-44. https://doi.org/10.1130/0091-7613(1983)11<40:SBGAFA>2.0.CO;2

Fernández, J., Martínez, E., Calderón, Y., Hermoza, W., \& Galdos, C. (2005). Tumbes and Talara basins hydrocarbon evaluation, Perupetro S.A., Basin Evaluations Group Exploration Department, internal report (pp. 130). Retrieved from www.perupetro.com.pe

Fildani, A., Hessler, A. M., \& Graham, S. A. (2008). Trench-forearc interactions reflected in the sedimentary fill of Talara basin, northwest Peru. Basin Research, 20(3), 305-331. https://doi.org/10.1111/j.1365-2117.2007.00346.x

Haq, S. S. B., \& Davis, D. M. (2010). Mechanics of fore-arc slivers: Insights from simple analog models. Tectonics, 29, TC5015. https://doi. org/10.1029/2009TC002583

Herms, P., John, T., Bakker, R. J., \& Schenk, V. (2012). Evidence for channelized external fluid flow and element transfer in subducting slabs (Raspas complex, Ecuador). Chemical Geology, 310-311, 79-96.

Hessler, A. M., \& Fildani, A. (2015). Andean forearc dynamics, as recorded by detrital zircon from the Eocene Talara basin, northwest Peru. Journal of Sedimentary Research, 85(6), 646-659. https://doi.org/10.2110/jsr.2015.45

Heuret, A., Conrad, C. P., Funiciello, F., Lallemand, S., \& Sandri, L. (2012). Relation between subduction megathrust earthquakes, trench sediment thickness and upper plate strain. Geophysical Research Letters, 39, L05304. https://doi.org/10.1029/2011GL050712

Hughes, R. A., \& Pilatasig, L. F. (2002). Cretaceous and Tertiary terrane accretion in the Cordillera Occidental of the Andes of Ecuador. Tectonophysics, 345(1-4), 29-48. https://doi.org/10.1016/S0040-1951(01)00205-0

Hungerbühler, D., Steinmann, M., Winkler, W., Seward, D., Egüez, A., Peterson, D. E., et al. (2002). Neogene stratigraphy and Andean geodynamics of southern Ecuador. Earth-Science Reviews, 57(1-2), 75-124. https://doi.org/10.1016/S0012-8252(01)00071-X

Jaillard, E., Benitez, S., \& Mascle, G. H. (1997). Palaeogene deformations of the forearc zone of south Ecuador in relation to the geodynamic evolution. Bulletin de la Societe Geologique de France, 168(4), 403-403.

Jaillard, E., Lapierre, H., Ordonez, M., Toro Alava, J., Amortegui, A., \& Vanmelle, J. (2009). Accreted oceanic terranes in Ecuador; southern edge of the Caribbean plate? Geological Society Special Publication, 328(1), 469-485. https://doi.org/10.1144/SP328.19

Jaillard, E., Laubacher, G., Bengtson, P., Dhondt, A. V., \& Bulot, L. G. (1999). Stratigraphy and evolution of the Cretaceous forearc CelicaLancones basin of southwestern Ecuador. Journal of South American Earth Sciences, 12(1), 51-68. https://doi.org/10.1016/S08959811(99)00006-1

Jaillard, E., Ordoñez, M., Benitez, S., Berrones, G., Jiménez, N., Montenegro, G., \& Zambrano, I. (1995). Basin development in an accretionary, oceanic-floored fore-arc setting: Southern coastal Ecuador during late Cretaceous-Late Eocene time. In A. J. Tankard, S. R. Suarez, \& H. J. Welsink (Eds.), Petroleum basins of South America (Vol. 62, pp. 615-631). Tulsa: AAPG.

Kellogg, J. N., Vega, V., Stailings, T. C., Aiken, C. L. V., \& Kellogg, J. N. (1995). In P. Mann (Ed.), p. 0Tectonic development of Panama, Costa Rica, and the Colombian Andes: Constraints from Global Positioning System geodetic studies and gravity Geologic and Tectonic Development of the Caribbean Plate Boundary in Southern Central America. America: Geological Society.

Kennan, L., \& Pindell, J. L. (2009). Dextral shear, terrane accretion and basin formation in the Northern Andes: Best explained by interaction with a Pacific-derived Caribbean Plate? Geological Society - Special Publications, 328, 487-531.

Kerr, A. C., Aspden, J. A., Tarney, J., \& Pilatasig, L. F. (2002). The nature and provenance of accreted oceanic terranes in western Ecuador: Geochemical and tectonic constraints. Journal of the Geological Society of London, 159, 577-594.

Kerr, A. C., Marriner, G. F., Tarney, J., Nivia, A., Saunders, A. D., Thirlwall, M. F., \& Sinton, C. W. (1997). Cretaceous basaltic terranes in western Colombia: Elemental, chronological and Sr-Nd isotopic constraints on petrogenesis. Journal of Petrology, 38(6), 677-702.

Kerr, A. C., \& Tarney, J. (2005). Tectonic evolution of the Caribbean and northwestern South America: The case for accretion of two Late Cretaceous oceanic plateaus. Geology, 33(4), 269-272.

Kopp, H. (2013). Invited review paper: The control of subduction zone structural complexity and geometry on margin segmentation and seismicity. Tectonophysics, 589, 1-16.

Luzieux, L., Heller, F., Spikings, R., Vallejo, C. F., \& Winkler, W. (2006). Origin and Cretaceous tectonic history of the coastal Ecuadorian forearc between 1 degrees $\mathrm{N}$ and 3 degrees S: Paleomagnetic, radiometric and fossil evidence. Earth and Planetary Science Letters, 249(3-4), 400-414.

Malatesta, C., Gerya, T., Crispini, L., Federico, L., \& Capponi, G. (2013). Oblique subduction modeling indicates along-trench tectonic transport of sediments. Nature Communications, 4

Mamberti, M., Lapierre, H., Bosch, D., Jaillard, E., Ethien, R., Hernandez, J., \& Polve, M. (2003). Accreted fragments of the Late Cretaceous Caribbean- Colombian Plateau in Ecuador. Lithos, 66(3-4), 173-199.

Mason, W. G., Moresi, L., Betts, P. G., \& Miller, M. S. (2010). Three-dimensional numerical models of the influence of a buoyant oceanic plateau on subduction zones. Tectonophysics, 483(1-2), 71-79.

McCaffrey, R. (1992). Oblique plate convergence, slip vectors, and fore-arc deformation. Journal of Geophysical Research, 97(B6), 8905-8915.

Michaud, F., Royer, J.-Y., \& Witt, C. (2009). Influence of the subduction of the Carnegie volcanic ridge on Ecuadorian geology: Reality and fiction. In V. A. R. S. M. Kay \& R. D. William (Eds.), Backbone of the Americas: Shallow subduction, plateau uplift, and ridge and terrane collision (pp. 217-228). America: Geological Society.

Mitouard, P., Kissel, C., \& Laj, C. (1990). Postoligocene rotations in southern Ecuador and northern Peru and the formation of the Huancabamba deflection in the Andean Cordillera. Earth and Planetary Science Letters, 98(3-4), 329-339.

Moreno, A. (1983), Estratigrafía detallada del Grupo Azúcar en los acantilados de Playas, Escuela Superior Politécnica del Litoral, 182.

Moresi, L., Betts, P. G., Miller, M. S., \& Cayley, R. A. (2014). Dynamics of continental accretion. Nature, $508,245$.

Mourier, T., Laj, C., Megard, F., Roperch, P., Mitouard, P., \& Medrano, A. F. (1988). An accreted continental terrane in northwestern Peru. Earth and Planetary Science Letters, 88(1-2), 182-192.

Nocquet, J. M., Villegas-Lanza, C., Chlieh, M., Mothes, P. A., Rolandone, F., Jarrin, P., et al. (2014). Motion of continental slivers and creeping subduction in the northern Andes (vol 7, pg 287, 2014). Nature Geoscience, 7(8), 287-291. 
Noda, A. (2016). Forearc basins: Types, geometries, and relationships to subduction zone dynamics. Geological Society of America Bulletin, $128(5-6), 879-895$.

Ordoñez, M. (1995). Zona de radiolarios del Eoceno medio del grupo Ancon, Peninsula de Santa Elena, Ecuador, Asociación Paleontológica Argentina(3).

Pinet, N., \& Cobbold, P. R. (1992). Experimental insights into the partitioning of motion within zones of oblique subduction. Tectonophysics, 206(3-4), 371-388.

Platt, J. P. (1993). Mechanics of oblique convergence. Journal of Geophysical Research, 98(B9), 16,239-16,256.

Reynaud, C., Jaillard, E., Lapierre, H., Mamberti, M., \& Mascle, G. H. (1999). Oceanic plateau and island arcs of southwestern Ecuador: Their place in the geodynamic evolution of northwestern South America. Tectonophysics, 307(3-4), 235-254.

Roperch, P., Megard, F., Laj, C., Mourier, T., Clube, T. M., \& Noblet, C. (1987). Rotated oceanic blocks in western Ecuador. Geophysical Research Letters, 14(5), 558-561.

Sanchez, J., Palacios, O., Feininger, T., Carlotto, V., \& Quispesivana, L. (2006). Puesta en evidencia de granitoides triásicos en los Amotapes-Tahuin: Deflexión de Huancabamba, XIII Congreso Peruano deGeologia (pp. 312-315). Lima, Peru: Sociedad Geologica, del Peru.

Sandwell, D. T., Muller, R. D., Smith, W. H. F., Garcia, E., \& Francis, R. (2014). New global marine gravity model from CryoSat-2 and Jason1 reveals buried tectonic structure. Science, 346(6205), 65-67.

Seely, D. R. (1979). The evolution of structural highs bordering major forearc basins. Memoir - American Association of Petroleum Geologists, 29, 245-260.

Spikings, R., Crowhurst, P. V., Winkler, W., \& Villagomez, D. (2010). Syn- and post-accretionary cooling history of the Ecuadorian Andes constrained by their in-situ and detrital thermochronometric record. Journal of South American Earth Sciences, 30(3), 121-133.

Spikings, R. A., Winkler, W., Hughes, R. A., \& Handler, R. (2005). Thermochronology of allochthonous terranes in Ecuador: Unraveling the accretionary and post-accretionary history of the Northern Andes. Tectonophysics, 399(1-4), 195-220.

Vallejo, C., Winkler, W., Spikings, R. A., Luzieux, L., Heller, F., \& Bussy, F. (2009). Mode and timing of terrane accretion in the forearc of the Andes in Ecuador. Geological Society of America Memoirs, 204, 197-216.

Van Melle, J., Vilema, W., Faure-Brac, B., Ordonez, M., Lapierre, H., Jimenez, N., et al. (2008). Pre-collision evolution of the Pinon oceanic terrane of SW Ecuador: stratigraphy and geochemistry of the "Calentura Formation". Bulletin de la Societe Geologique de France, 179(5), 433-443.

Vogt, K., \& Gerya, T. V. (2014). From oceanic plateaus to allochthonous terranes: Numerical modeling. Gondwana Research, 25(2), 494-508.

Von Huene, R., \& Scholl, D. W. (1991). Observations at convergent margins concerning sediment subduction, subduction erosion, and the growth of continental-crust. Reviews of Geophysics, 29(3), 279-316.

Wallace, L. M., Ellis, S., \& Mann, P. (2009). Collisional model for rapid fore-arc block rotations, arc curvature, and episodic back-arc rifting in subduction settings. Geochemistry, Geophysics, Geosystems, 10, Q05001. https://doi.org/10.1029/2008GC002220

Wallace, L. M., McCaffrey, R., Beavan, J., \& Ellis, S. (2005). Rapid microplate rotations and backarc rifting at the transition between collision and subduction. Geology, 33(11), 857-860.

Whattam, S. A., \& Stern, R. J. (2015). Late Cretaceous plume-induced subduction initiation along the southern margin of the Caribbean and NW South America: The first documented example with implications for the onset of plate tectonics. Gondwana Research, 27(1), 38-63.

Winkler, W., Villagómez, D., Spikings, R., Abegglen, P., Tobler, S., \& Egüez, A. (2005). The Chota basin and its significance for the inception and tectonic setting of the inter-Andean depression in Ecuador. Journal of South American Earth Sciences, 19(1), 5-19.

Winter, L. S., Tosdal, R. M., Mortensen, J. K., \& Franklin, J. M. (2010). Volcanic stratigraphy and geochronology of the Cretaceous Lancones basin, northwestern Peru: Position and timing of giant VMS deposits. Economic Geology, 105(4), 713-742.

Witt, C., Aizprua, C., Reynaud, J. Y., Amberg, C., \& Poujol, M. (2018). An U-Pb zircon chronology based correlation for forearc sediments through the Ecuadorian - Peruvian border. Paper presented at Réunion des Sciences de la Terre, Lille-France, 22-26 October.

Witt, C., \& Bourgois, J. (2010). Forearc basin formation in the tectonic wake of a collision-driven, coastwise migrating crustal block: The example of the North Andean block and the extensional Gulf of Guayaquil-Tumbes basin (Ecuador-Peru border area). Geological Society of America Bulletin, 122(1-2), 89-108.

Witt, C., Bourgois, J., Michaud, F., Ordonez, M., Jimenez, N., \& Sosson, M. (2006). Development of the Gulf of Guayaquil (Ecuador) during the Quaternary as an effect of the North Andean block tectonic escape. Tectonics, 25, TC3017. https://doi.org/10.1029/2004TC001723

Witt, C., Reynaud, J. Y., Barba, D., Poujol, M., Aizprua, C., Rivadeneira, M., \& Amberg, C. (2019). From accretion to forearc basin initiation: The case of SW Ecuador, northern Andes. Sedimentary Geology, 379, 138-157.

Witt, C., Rivadeneira, M., Poujol, M., Barba, D., Beida, D., Beseme, G., \& Montenegro, G. (2017). Tracking ancient magmatism and Cenozoic topographic growth within the Northern Andes forearc: Constraints from detrital U-Pb zircon ages. Geological Society of America Bulletin, 129(3-4), 415-428. https://doi.org/10.1130/B31530.1

Yepes, H., Audin, L., Alvarado, A., Beauval, C., Aguilar, J., Font, Y., \& Cotton, F. (2016). A new view for the geodynamics of Ecuador: Implication in seismogenic source definition and seismic hazard assessment. Tectonics, 35, 1249-1279. https://doi.org/10.1002/ 2015 TC003941 